\title{
Mutations in Spike Protein of SARS-CoV-2 Modulate Receptor Binding, Membrane Fusion and Immunogenicity: An Insight into Viral Tropism and Pathogenesis of COVID-19
}

Dr. Priyanka Saha, Ranabir Majumder, sourabrata chakraborty, Amit Kumar Srivastava, Mahitosh Mandal, Siddik Sarkar

Submitted date: 18/05/2020 - Posted date: 19/05/2020

Licence: CC BY-NC-ND 4.0

Citation information: Saha, Dr. Priyanka; Majumder, Ranabir; chakraborty, sourabrata; Kumar Srivastava, Amit; Mandal, Mahitosh; Sarkar, Siddik (2020): Mutations in Spike Protein of SARS-CoV-2 Modulate Receptor Binding, Membrane Fusion and Immunogenicity: An Insight into Viral Tropism and Pathogenesis of COVID-19. ChemRxiv. Preprint. https://doi.org/10.26434/chemrxiv.12320567.v1

SARS-CoV-2 uses RBD of Spike (S) protein to attach with human cell via ACE2 receptor, followed by protease priming at $\mathrm{S} 1 / \mathrm{S} 2$ site resulted in host cell entry and pathogenesis. In this context, we focused our aim in studying natural mutations harboring in Spike protein of SARS-CoV-2. We have analyzed 420 COVID-19 cases. G476S and V483G mutation are observed which lies in the RBD region where as the prevalent D614G mutation is observed in the vicinity of $\mathrm{S} 1 / \mathrm{S} 2$ site. Interestingly MD simulation supports strong favorable interaction of ACE2 with RBD region containing V483A mutation as compared to G476S and reference wild Wuhan $S$ protein. Radius of gyration analysis also showed high degree of compactness in V483A. The landscape plot and Gibbs free energy also support our findings. Overall, our study indicates that V483G in the RBD region can enhance its binding with the human ACE2 receptor. Interestingly D614G mutation in vicinity of $\mathrm{S} 1 / \mathrm{S} 2$ region introduced a new cleavage site specific for a serine protease elastase that is anticipated to broaden the virus host cell tropism. Hence, both V483A and D614G mutations led to enhanced and broaden the virus host cell entry and transmission of the disease. Further epitope mapping analysis revealed G476S and D614G mutations as antigenic determinants and thus these mutations are important while designing a therapeutics vaccine or chimeric antibody. This finding will help in further understanding the role of such arising mutations in modulating immunogenicity, viral tropism and pathogenesis of the disease, which in lieu will help in designing vaccine more precisely to mitigate pandemic COVID-19.

File list (2)

FINAL VERSION.pdf (2.88 MiB)

view on ChemRxiv • download file 


\section{TITLE:}

Mutations in Spike protein of SARS-CoV-2 modulate receptor binding, membrane fusion and immunogenicity: an insight into viral tropism and pathogenesis of COVID-19

RUNNING TITLE: Common mutations in Spike protein of SARS-CoV-2 in COVID-19

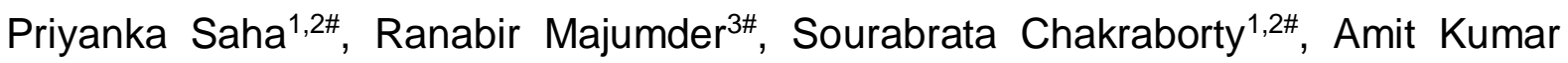
Srivastava ${ }^{1,2}$, Mahitosh Mandal ${ }^{3}$, Siddik Sarkar ${ }^{1,2 *}$

${ }^{1}$ Cancer Biology \& Inflammatory Disorder Division, CSIR-Indian Institute of Chemical Biology (IICB), Kolkata, WB-700032, INDIA.

${ }^{2}$ IICB-Translational Research Unit of Excellence, Salt Lake, WB-700091, INDIA

${ }^{3}$ School of Medical Science and Technology, Indian Institute of Technology Kharagpur, WB-721302, INDIA

\#Authors sharing joint first authorship

*Corresponding author: Dr. Siddik Sarkar

Email: siddik.sarker@iicb.res.in

Ph. No: +91-33-23403000. Ext. 3008 (Office), +91 9903936753 (Home) 


\section{Abstract:}

SARS-CoV-2 uses RBD of Spike (S) protein to attach with human cell via ACE2 receptor, followed by protease priming at $\mathrm{S} 1 / \mathrm{S} 2$ site resulted in host cell entry and pathogenesis. In this context, we focused our aim in studying natural mutations harboring in Spike protein of SARS-CoV-2. We have analyzed 420 COVID-19 cases. G476S and V483G mutation are observed which lies in the RBD region where as the prevalent D614G mutation is observed in the vicinity of $\mathrm{S} 1 / \mathrm{S} 2$ site. Interestingly MD simulation supports strong favorable interaction of ACE2 with RBD region containing V483A mutation as compared to G476S and reference wild Wuhan S protein. Radius of gyration analysis also showed high degree of compactness in V483A. The landscape plot and Gibbs free energy also support our findings. Overall, our study indicates that $\mathrm{V} 483 \mathrm{G}$ in the RBD region can enhance its binding with the human ACE2 receptor. Interestingly D614G mutation in vicinity of S1/S2 region introduced a new cleavage site specific for a serine protease elastase that is anticipated to broaden the virus host cell tropism. Hence, both V483A and D614G mutations led to enhanced and broaden the virus host cell entry and transmission of the disease. Further epitope mapping analysis revealed G476S and D614G mutations as antigenic determinants and thus these mutations are important while designing a therapeutics vaccine or chimeric antibody. This finding will help in further understanding the role of such arising mutations in modulating immunogenicity, viral tropism and pathogenesis of the disease, which in lieu will help in designing vaccine more precisely to mitigate pandemic COVID-19.

Key Words: SARS-CoV-2, Spike (S) protein, Receptor binding domain (RBD), Viral tropism, Mutation, Binding interaction. 


\section{Introduction}

Corona viral disease 2019 (COVID-19) has become one of the worst pandemics in human history. Since its emergence in December 2019 in Wuhan, China 1,2 it has spread across 210 countries and territories around the globe with $\sim 4,000,000$ reported cases and death toll of 300,000 as on 9th May $2020{ }^{3}$. COVID-19 caused by Severe acute respiratory syndrome-related coronavirus 2 (SARS-CoV-2) is the third instance in less than two decades where a zoonotic coronavirus has crossed the species barrier and infected humans after severe acute respiratory syndrome related coronavirus (SARS-CoV) ${ }^{4}$ and Middle-East respiratory syndrome related coronavirus (MERS-CoV) ${ }^{5}$. SARS-CoV-2 belongs to the $\beta$-coronavirus genus same as SARS and MERS. Studies indicate that SARS-CoV2 probably originated in bats ${ }^{2}$ similarly as SARS-CoV ${ }^{6,7}$ and MERS ${ }^{8}$.

SARS-CoV-2 bears a significant similarity with SARS-CoV even uses the same receptor angiotensin converting enzyme II (ACE2) for host cell entry 2, 9. Coronaviruses use surface spike (S) glycoprotein for host cell entry, it has two functional domain S1 and S2 which helps in host cell receptor binding and fusion of viral membrane with cellular membrane respectively ${ }^{10}$. Both the SARS-CoV and SARS-CoV-2 uses the C-terminal domain of S1 for receptor binding ${ }^{11,12}$ but SARSCoV-2 spike protein binds more strongly with human ACE2 than SARS spike protein 9,13 . The RBD region of the spike protein falls in the secondary structure and is responsible for host interaction. Mutation is the several lines of the strain has shown to increase the infectivity ${ }^{14,15}$. Spike proteins show a high amount of antigenicity, which is evident from the fact that Convalescent plasma from SARS patients show a high percentage of anti-S neutralizing antibodies ${ }^{15,16}$.

Given the importance of spike protein in viral entry and arising mutation amongst the different variations, we try to focus on the different mutations of spike protein in SARS-CoV-2 patients across the globe and their probable interaction with the human cell, the information of which altogether will facilitate in efficient development of vaccine and effective drug.

\section{Results:}

\section{Evolutionary relationship among Coronaviruses}


The $\beta$-coronavirus genome sequences encompassing SARS-CoV-2 SARS, MERS, Bat CoV RaTG13 (host bat), Pangolin CoV (host pangolin) were collected from the NCBI Virus repository and the sequences were analyzed using public interface Basic Local Alignment Search Tool (BLAST; https://blast.ncbi.nlm.nih.gov/Blast). To study evolutionary relationship, phylogenetic tree were constructed using MEGA $X$ : Molecular Evolutionary Genetics Analysis across Computing Platforms. As evident from Fig. 1 SARS-CoV2 showed closely related to Bat CoV RaTG13 and Pangolin CoV (Pang-CoV) than to SARS and it is more distantly related to MERS. There is $99.99 \%$ similarity among the SARS-CoV-2 whole genome sequences isolated from infected patients from different countries with respect to Wuhan $\mathrm{Hu}-1$ isolate (GenBank: MN908947.3) or reference sequence (RefSeq. NC_045512.2) (Suppl Table 1). There is also very high $(96.12 \%)$ identity of whole genome sequences obtained from Bat CoV RaTG13 suggesting that Bat CoV may be closest as par ancestor relationship is concerned. $85.42 \%$ similarity is observed with CoV obtained from Pangolin isolates. SARS sequences obtained from different isolates showed $\sim 80 \%$ identity. The least ( $67 \%)$ identity is observed in MERS isolates. Since maximum identity is observed with Bat CoV RaTG13, we further compared the different coding regions of Bat-CoV with SARS-CoV-2. The minimum identity (92.86\% identity) or maximum dissimilarity $(\sim 8 \%)$ lies in $S$ protein coding region as compared to other coding regions ( 96 to $99 \%$ ) between SARS-CoV-2 and Bat-CoV (Suppl. Table 2). SARS-CoV-2 showed divergence mainly in receptor binding domain (RBD) from bat coronavirus (Suppl. Fig. 1). Additionally, SARS-CoV2 shows the insertion of a polybasic furin cleavage site (Suppl. Fig. 1) at S1-S2 boundary unusual of other coronaviruses. 


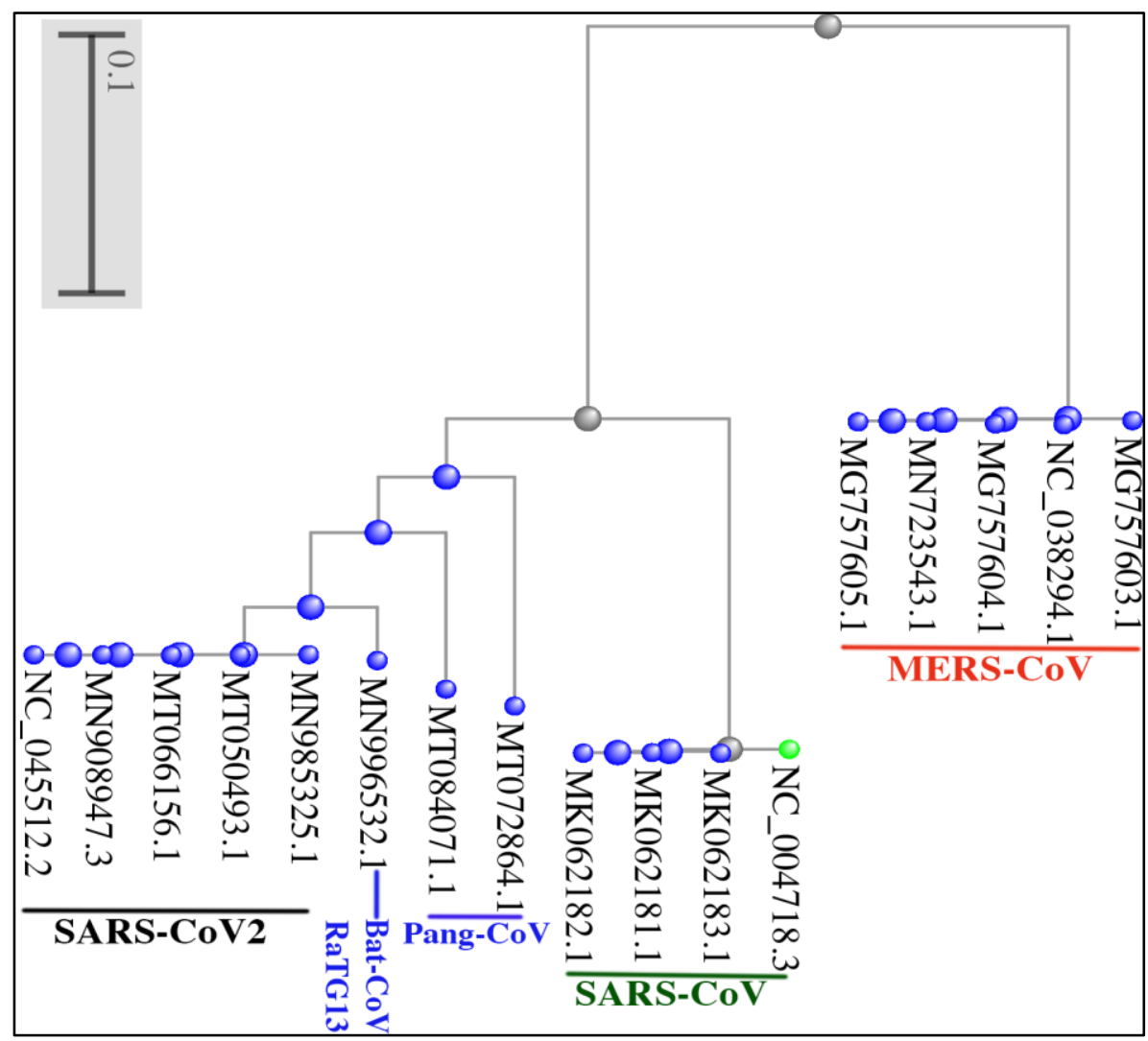

Figure 1: Evolutionary relationship among coronaviruses: The whole genome sequence of $\beta-\mathrm{CoV}$ is aligned and pylogentic analysis was performed. 


\section{Mutational analysis of Spike (S) protein}

We retrieved Spike protein sequences of 420 patients isolates across the globe and analyzed the mutational status of them and selected only those mutations which arises more than once in the population thereby getting only 9 such mutational groups. We found C13T, G1422A, G1426A, T1448C, A1841G, C2472T, A2763G, A3132T, A3132T base mutation that resulted in L5V, Q474Q, G476S, V483A, D614G, N824N, K921K, G1044G, and D1259D amino acid substitution mutations. (Fig. 2, Table 1 and Suppl. File 3). Since the RBD and S1/S2 periphery region plays a pivotal role in host cell entry and disease transmission, we further characterize the mutations G476S, V483A and D614G that lies respectively in RBD, RBD and S1/S2 junction. G476S, V483A and D614G mutation constitutes $0.71 \%$ (3/420), 1.21\% (5/420) and $28.03 \%$ (118/420) of COVID-19 cases out of all 420 cases studied. 


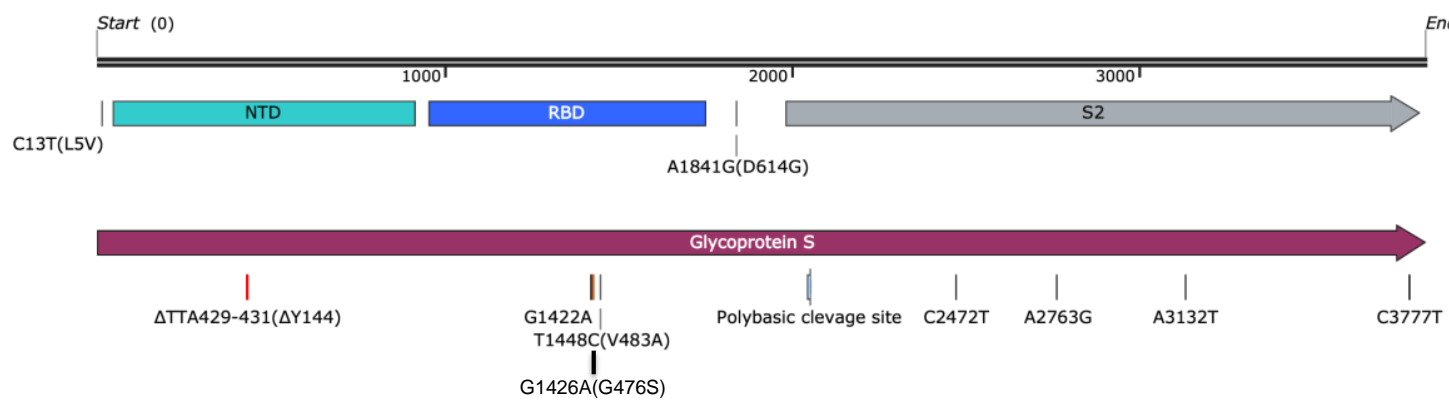

Figure 2: Mutations spanning different regions of Spike (S) protein. Nucleotide as well as amino acid mutation is depicted along with the position number with respect to SARS-CoV-2 Wuhan Hu-1 isolate.

Table 1: Spike protein mutations in COVID-19 cases

\begin{tabular}{|l|l|l|l|l|}
\hline $\begin{array}{c}\text { Nucleotide } \\
\text { Mutation }\end{array}$ & $\begin{array}{l}\text { Amino Acid } \\
\text { Substitution }\end{array}$ & Countries & $\begin{array}{l}\text { Number of cases/ } \\
\text { Total cases }\end{array}$ & $\%$ \\
\hline C13T & L5V & USA & $4 / 420$ & 0.95 \\
\hline G1422A* & Q474Q & USA & $3 / 420$ & 0.71 \\
\hline G1426A & G476S & USA & $3 / 420$ & 0.71 \\
\hline T1448C & V483A & USA & $5 / 420$ & 1.19 \\
\hline A1841G & D614G & $\begin{array}{l}\text { USA, Spain, } \\
\text { Peru, Israel }\end{array}$ & $118 / 420$ & 28.03 \\
\hline C2472T $^{*}$ & N824N & USA, Nepal & $9 / 420$ & 2.14 \\
\hline A2763G $^{*}$ & K921K & USA, China & $3 / 420$ & 0.71 \\
\hline A3132T $^{*}$ & G1044G & USA & $3 / 420$ & 0.71 \\
\hline C3777T $^{*}$ & D1259D & USA & $2 / 420$ & 0.48 \\
\hline
\end{tabular}

*synonymous nucleotide substitution 


\section{Homology modelling of SARS-CoV-2 Spike protein}

To study further the functional aspects of $S$ protein, we first modelled the $S$ protein of SARS-CoV-2. The Phyre2 program successfully constructed the SARSCoV-2 S protein (Fig. 3a) with $100 \%$ confidence and $82 \%$ coverage by using the homologue SARS-CoV spike glycoprotein (PDB: 5X5B, Chain B) template and the original SARS-CoV-2 protein sequence (GeneBank: MN908947). The RMSD value between template protein and modelled protein structure is 0.00 (Fig. 3b). Ramachandran plot has shown that $90.3 \%$ of modelled secondary protein structure residues are in the favoured region (Fig. 3c).
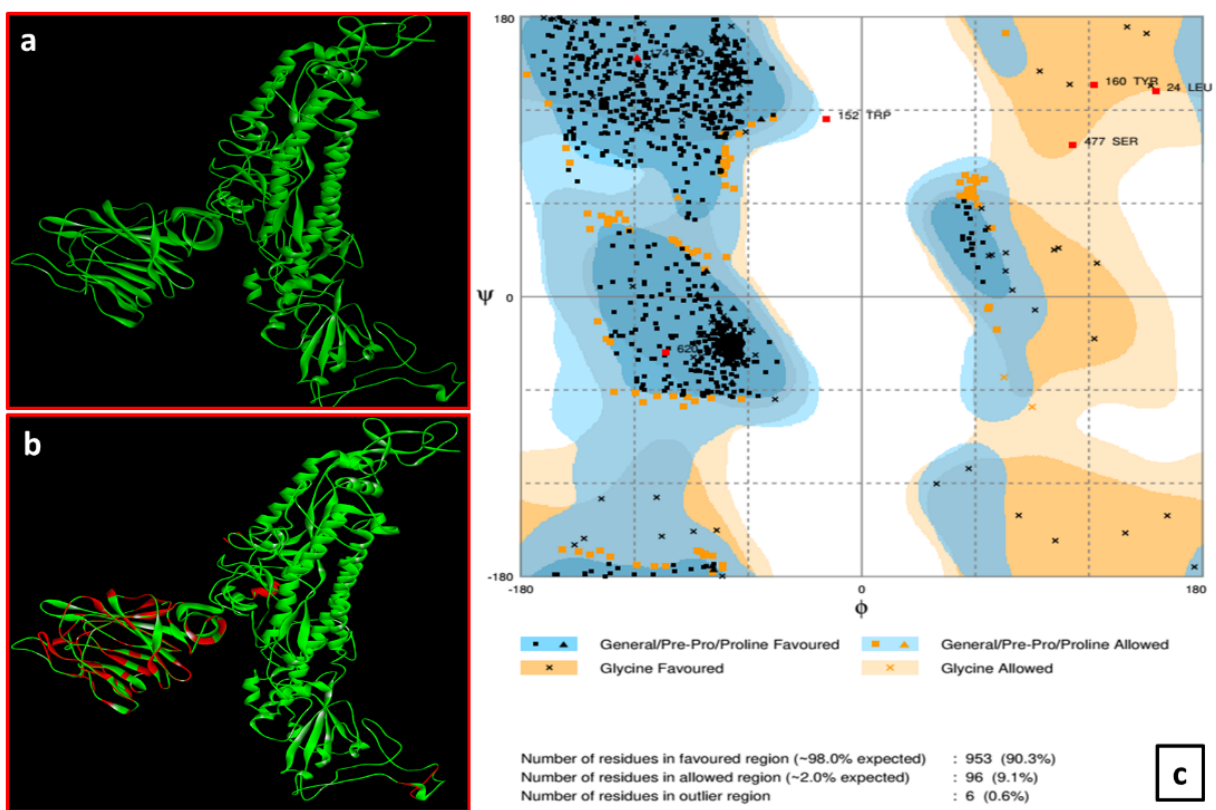

Figure 3: SARS-CoV2 spike protein modelling.

(a) Modelled SARS-CoV-2 spike protein. (b) Superimpose image of modelled SARSCoV-2 spike protein (green) and template SARS-CoV spike glycoprotein (red). (c) Ramachandran plot of modelled SARS-CoV-2 spike protein. 


\section{Mutant Spike protein binds more strongly with ACE2 receptor}

Among the mutations we found, two frequent mutations (G476S and V483A) lies in the RBD region (amino acid residue 333-526) ${ }^{17}$ of the SARS-CoV-2 spike protein. To study the functional aspects, we have taken our modelled SARS-CoV-2 S protein structure as a reference and mutated these two amino acid regions in a Mutated model_A (G476S and V483A) and also have done a single mutation in Mutated model_B (G476S) and Mutated model_C (V483A) (Fig.4).

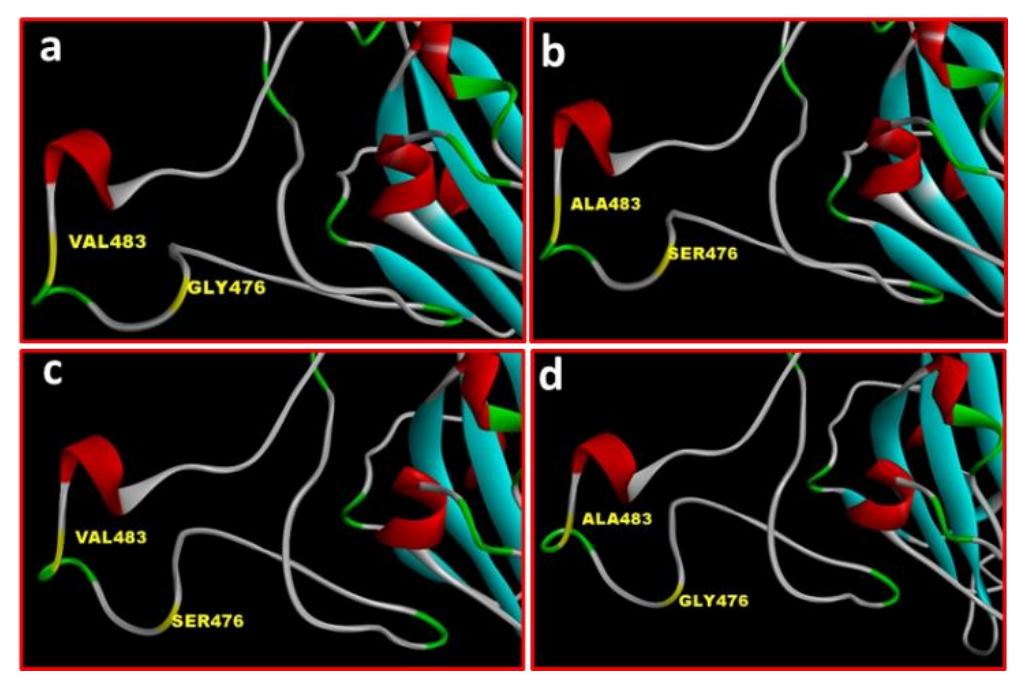

Figure 4: Structural changes due to the mutation in the amino acid residues in the S protein of SARS-CoV-2. (a) Reference (wild type Wuhan Hu-1 isolate), (b) Mutated model A (G476S and V483A), (c) Mutated model B (G476S), and (d) Mutated model C (V483A) of SARS-CoV-2 spike protein structure containing RBD region.

We have docked our modeled reference SARS-CoV-2 spike protein and its mutated models (Mutated_model_A, Mutated_model_B, and Mutated_model_C) receptorbinding domain (RBD) to the ACE2 receptor (Fig. 5). Our in silico docking results have shown that Mutated_model_B $(-379.75 \mathrm{kcal} / \mathrm{mol})$ and Mutated_model_A (-364.54 $\mathrm{kcal} / \mathrm{mol}$ ) have a higher binding affinity towards the ACE2 receptor as compared to reference SARS-CoV-2 spike protein $(-350.94 \mathrm{kcal} / \mathrm{mol})$. On the other hand, Mutated_model_C $(-309.06 \mathrm{kcal} / \mathrm{mol})$ has a lesser binding affinity towards the ACE2 
receptor as compared to reference SARS-CoV-2 spike protein. Such docking results (Table 2) indicate that mutations in reference SARS-CoV-2 spike protein are altering its structural conformation, which is influencing the binding interaction with the ACE2 receptor.

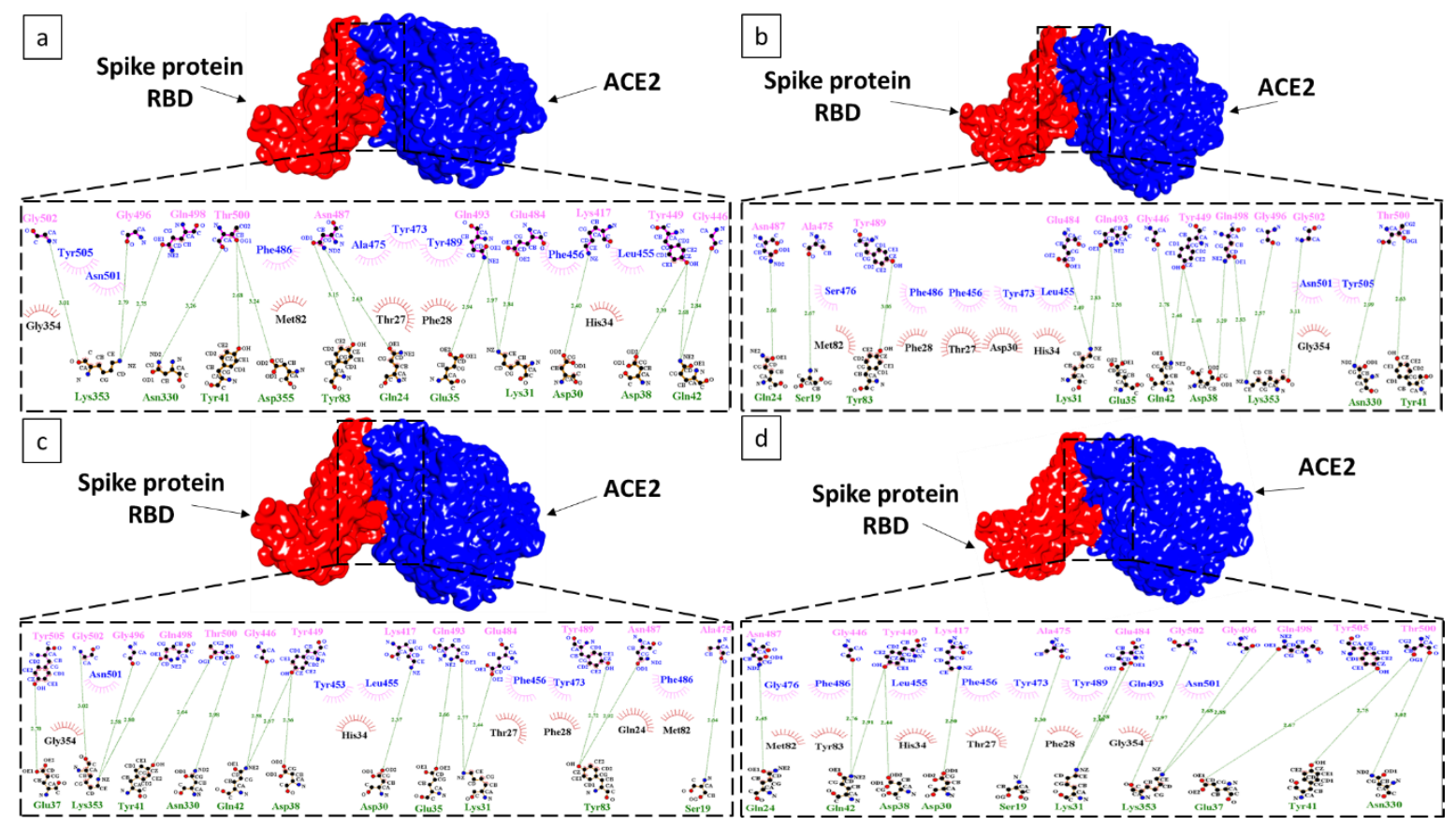

Figure 5: Interactions between SARS-CoV-2 spike protein RBD region and ACE2 receptor

(a) Reference (Wuhan Hu-1 isolate), (b) Mutated model_A (G473S and V483A), (c) Mutated model_B (G476A), and (d) Mutated model_C (V483A) RBD region of S protein. 
Table 2. Interaction between SARS-CoV-2 spike protein RBD region and ACE2 receptor

\begin{tabular}{|c|c|c|c|}
\hline $\begin{array}{l}\text { SARS-CoV-2 } \\
\text { spike protein }\end{array}$ & $\begin{array}{c}\text { Binding } \\
\text { Affinity } \\
\text { (kcal/mol) }\end{array}$ & $\begin{array}{l}\text { *H-bond (Distance } \AA \text { ) } \\
\text { interaction between } \\
\text { receptor-ligand amino } \\
\text { acid residues }\end{array}$ & $\begin{array}{l}{ }^{*} \text { Hydrophobic } \\
\text { interaction between } \\
\text { receptor-ligand } \\
\text { amino } \\
\text { acid residues }\end{array}$ \\
\hline Reference & -350.94 & $\begin{array}{c}\text { Lys353-Gly502, Gly496, Gln498 (3.01, 2.79, } \\
\text { 2.75), Asn330-Thr500 (3.26), Tyr41-Thr500 } \\
\text { (2.68), Asp355-Thr500 (3.24), Tyr83-Asn487 } \\
\text { (3.15), Gln24-Asn487 (2.63), Glu35-Gln493 } \\
\text { (2.94), Lys31-Gln493, Glu484 (2.97) (2.84), } \\
\text { Asp30-Lys47 (2.40), Asp38-Tyr449 (2.39), } \\
\text { Gln42- Tyr449, Gly446 (2.68), (2.84). }\end{array}$ & $\begin{array}{l}\text { Gly354, Tyr505, } \\
\text { Asn501, Met82, } \\
\text { Phe486, Thr27, } \\
\text { Phe28, Tyr473, } \\
\text { Ala475, Tyr489, } \\
\text { His34, Phe456, } \\
\text { Leu455. }\end{array}$ \\
\hline $\begin{array}{c}\text { Mutated } \\
\text { model_A } \\
\text { (G476S and } \\
\text { V483A }\end{array}$ & -364.54 & $\begin{array}{c}\text { Gln24-Asn487 (2.66), Ser19-Ala475 (2.67), } \\
\text { Tyr83-Tyr489 (3.06), Lys31-Gln484, Gln493 } \\
\text { (2.49, 2.83), Glu35-Gln493 (2.56), Gln42- } \\
\text { Gly446, Tyr449 (2.78, 2.46), Asp38-Tyr449, } \\
\text { Gln498 (2.48) (3.29), Lys353-Gln498, Gly496, } \\
\text { Gly502 (2.83, 2.57, 3.11), Asn330-Thr500 } \\
\text { (2.09), Tyr41-Thr500 (2.63) }\end{array}$ & $\begin{array}{l}\text { Ser476, Met82, } \\
\text { Phe486, Phe28, } \\
\text { Thr27, Asp30, His34, } \\
\text { Tyr473, Phe456, } \\
\text { Leu455, Gly354, } \\
\text { Asn501, Tyr505. }\end{array}$ \\
\hline $\begin{array}{l}\text { Mutated } \\
\text { model_B } \\
\text { (G476S) }\end{array}$ & -379.75 & $\begin{array}{l}\text { Glu37-Tyr505 (2.70), Lys353-Gly496, Gly502, } \\
\text { Gln498 (2.58, 3.82, 2.80), Tyr41-Thr500 } \\
\text { (2.64), Asn330-Thr500, Gln42-Gly446, Try449 } \\
\text { (2.58, 2.57), Asp38-Tyr449 (2.36), Asp30- } \\
\text { Lys417 (2.37), Glu35-GIn493 (2.66), Lys31- } \\
\text { Gln493, Gln484 (2.77, 2.44), Tyr83-Tyr489, } \\
\text { Asn487 (2.72, 2.92), Ser19-Ala475 (2.64). }\end{array}$ & $\begin{array}{l}\text { Gly354, Asn501, } \\
\text { His34, Tyr453, } \\
\text { Leu455, Thr27, } \\
\text { Phe28, Phe456, } \\
\text { Tyr473, GIn24, } \\
\text { Met82, Phe486. }\end{array}$ \\
\hline $\begin{array}{l}\text { Mutated } \\
\text { model_C } \\
(\mathrm{V} 483 \mathrm{~A})\end{array}$ & -309.06 & $\begin{array}{c}\text { Gln24-Asn487 (2.45), Gln42-Gly446, Tyr449 } \\
\text { (2.76, 2.91), Asp38-Tyr449 (2.44), Asp30- } \\
\text { Lys417 (2.50), Ser19-Ala475 (2.30), Lys31- } \\
\text { Glu484 (2.40, 2.58), Lys353-Gly502, Gly496, } \\
\text { Gln498 (2.97, 2.68, 2.88), Glu37-Tyr505 } \\
\text { (2.67), Tyr41-Thr500 (2.75), Asn330-Thr500 } \\
\text { (3.02). }\end{array}$ & $\begin{array}{l}\text { Met82, Tyr83, } \\
\text { Gly476, Phe486, } \\
\text { His34, Leu455, } \\
\text { Thr27, Phe456, } \\
\text { Tyr473, Phe28, } \\
\text { Tyr489, Gly354, } \\
\text { Gln493, Asn501, }\end{array}$ \\
\hline
\end{tabular}

*Spike protein residues in blue and ACE2 receptor protein residues in black. 


\section{Molecular dynamics simulation}

We have run $20 \mathrm{~ns}$ molecular dynamics (MD) simulation to investigate stability, flexibility, and non-bonded interaction of ACE2 receptor complexes docked with four different modelled SARS-CoV-2 spike protein RBD region, which are Reference, Mutated_model_A, Mutated_model_B, and Mutated_model_C. From that MD simulation trajectory, we have calculated root mean square deviation (RMSD), root mean square fluctuation (RMSF), radius of gyration $(\mathrm{Rg})$, Interaction energy, number of Hydrogen bond, Gibbs free energy landscape and also performed principle component analysis, secondary structural analysis to check conformational properties of docked complexes such as stability, flexibility, and non-bonded interaction strength.

\section{RMSD Analysis}

Root mean square deviation (RMSD) signifies the stability of protein-protein complex structure. Here, the RMSD values of all the four different modelled SARSCoV-2 spike protein RBD region docked into ACE2 receptor have been compared (Fig.5a). It has been observed that the average RMSD value for docked complexes of ACE2 receptor with Reference, Mutated_model_A, Mutated_model_B, and Mutated_model_C are $0.36 \mathrm{~nm} \pm 0.057,0.25 \mathrm{~nm} \pm 0.028,0.44 \mathrm{~nm} \pm 0.097$, and 0.30 $\mathrm{nm} \pm 0.043$ respectively. Such result shows that Mutated_model_A and Mutated_model_C have higher stability when they interact with ACE2 receptor as compare to Reference and Mutated_model_B, as protein complex with lower RMSD value will form more stable structural conformation.

\section{RMSF Analysis}

Root mean square fluctuation (RMSF) denotes flexibility of amino acid residual. Flexibility of amino acid residues present in protein-protein complexes (four different modelled SARS-CoV-2 spike protein RBD region-ACE2 receptor complexes) has been analysed (Fig.5.b). Here, residue index 1-597 represents ACE2 receptor and 598-791 represents SARS-CoV-2 spike protein RBD region. Less or minimal fluctuation has been observed in amino acid residues of ACE2 receptor complexes docked with Reference, Mutated_model_A, Mutated_model_B, and Mutated_model_C $(0.144 \mathrm{~nm} \pm 0.053,0.130 \mathrm{~nm} \pm 0.051,0.179 \mathrm{~nm} \pm 0.070$, and 0.145 $\mathrm{nm} \pm 0.052$ respectively). Such results indicate that amino acid residue fluctuation is higher in Mutated_model_B-ACE2 receptor complex as compared to three others. 
Besides that, RMSF value is very high in N-terminal amino acid residue (THR) of SARS-CoV-2 spike protein RBD region of Mutated_model_A $(0.7044 \mathrm{~nm})$, and Mutated_model_C $(0.6033 \mathrm{~nm})$. Also, in C-terminal amino acid residues (LEU, HIS, ALA, PRO, THR, VAL, CYS, and GLY) of Mutated_model_B have a high fluctuation up to $0.528 \mathrm{~nm}$. These types of fluctuations indicate dynamical change behaviour of the secondary structure during the interaction between these modelled SARS-CoV-2 spike protein $\mathrm{RBD}$ region and ACE2 receptor.

\section{Radius of gyration (Rg) Analysis}

$\mathrm{Rg}$ indicates the compactness, stability, and folding of structure. We have calculated the $\mathrm{Rg}$ based on the intrinsic dynamics of docked complex of ACE2 receptor with four different modelled SARS-CoV-2 spike protein RBD region (Fig.5.c). We have observed that all the protein-protein complexes have overall steady average of Rg. But Mutated_model_A and Mutated_model_C have more compactness and stability when they interact with ACE2 receptor as compared to two others modelled SARS-CoV-2 spike protein RBD region.

\section{Interaction Energy Analysis}

Interaction energy determines the strength of non-bonded protein-protein interaction in a dynamic environment. We have calculated the short-range Coulombic interaction energy between ACE receptor and all four different modelled SARS-CoV2 spike protein RBD region (Fig.5.d). It has been observed that non-bonded interaction of Mutated_model_C $\left(-2.320 \times 10^{5} \mathrm{Kcal} / \mathrm{mol}\right)$ and Mutated_model_A ($2.315 \times 10^{5} \mathrm{Kcal} / \mathrm{mol}$ ) with ACE2 receptor is found to be stronger as compared to Reference $\left(-2.307 \times 10^{5} \mathrm{Kcal} / \mathrm{mol}\right)$ and Mutated_model_B $\left(-2.307 \times 10^{5} \mathrm{Kcal} / \mathrm{mol}\right)$. Such results have shown that Mutated_model_C and Mutated_model_A with a lower average of interaction energy hold a good amount of non-bonded interaction strength during the whole simulation.

\section{Hydrogen Bond Analysis}

The number of Hydrogen bond, which are the main interaction stabilizing factor between two molecules, have been calculated to investigate the nature of $\mathrm{H}$-bond 
between ACE2 receptor and all four different modelled SARS-CoV-2 spike protein $\mathrm{RBD}$ region (Fig.5.e). The number of $\mathrm{H}$-bond has been recorded throughout the $20 \mathrm{~ns}$ $\mathrm{MD}$ simulation. It has been found that the average number of $\mathrm{H}$-bonds between ACE2 receptor and Mutated_model_A, Mutated_model_C, Mutated_model_B, and Reference model are $9.635 \pm 1.92,7.283 \pm 1.568,6.20 \pm 1.922$, and 5.651 respectively. Such results suggest that Mutated_model_A and Mutated_model_C have formed higher number of stable $\mathrm{H}$-Bonds when they interact with $\mathrm{ACE} 2$ receptor as compared to Reference and Mutated_model_B.
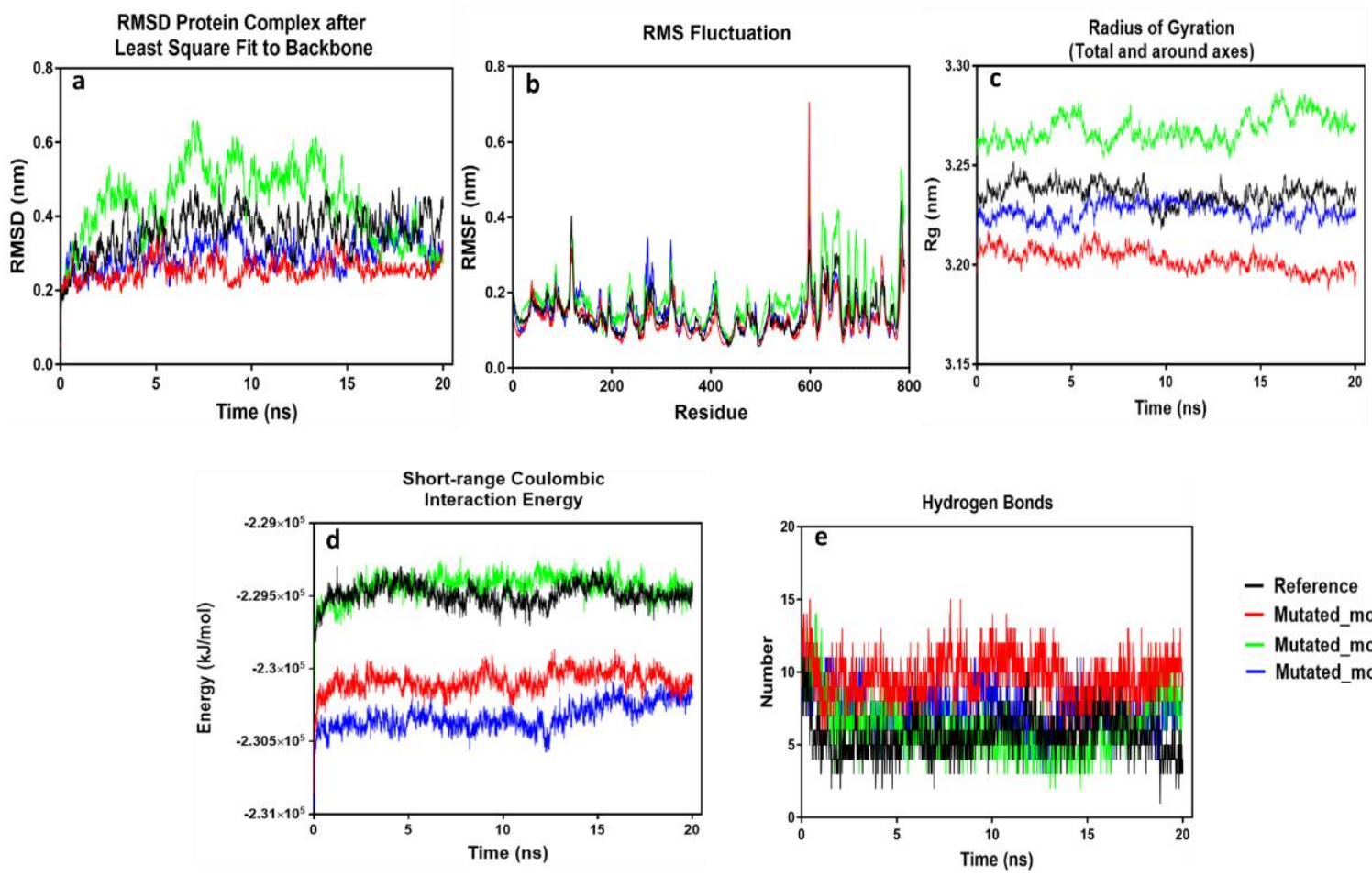

- Reference

- Mutated_model_A

- Mutated_model_B

- Mutated_model_C

Figure 5. (a) RMSD, (b) RMSF, (c) Radius of gyration (Rg), (d) Short-range Coulombic interaction energy, and (e) Number of hydrogen bond analysis for all the four different modelled SARS-CoV-2 spike protein RBD region docked into ACE2 receptor. 


\section{Principal Component Analysis}

The collective movement of the atoms in the ACE2 receptor complexes docked with four different modelled SARS-CoV-2 spike protein RBD region have been analyzed using the MD trajectories projected on principal components (PC1 and PC2) to obtain a better understanding of the conformational changes in protein-protein complexes. Here, it has been observed that there are lesser distribution of dots when ACE2 receptor interacts with Mutated_model_A and Mutated_model_C as compared to Reference and Mutated_model_B (Fig.6). These results suggest that ACE2 receptor forms highly stable and compact complex when it interacts with Mutated_model_A and Mutated_model_C as compared to Reference and Mutated_model_B.

The flexibility of the ACE2 receptor complexes docked with four different modelled SARS-CoV-2 spike protein RBD region have been analyzed to a larger extent by estimating the trace value for the diagonalized covariance matrix, which is a matrix of Eigenvectors and diagonal Eigenvalues. The Eigenvectors indicate the general direction of motion of the atoms, while the Eigenvalues signify the atomic influence in the movement. Fig.7 shows the diagonalized covariance matrix of ACE2 receptor complexes with all four different modelled SARS-CoV-2 spike protein RBD region. The trace values, which are the sums of the Eigenvalues, are 29.136, 18.880, 18.551, and $15.412 \mathrm{~nm}^{2}$ for the ACE2 receptor complex with Mutated_model_B, Mutated_model_C, Reference, and Mutated_model_A respectively. These results show that ACE2 complexes with Mutated_model_A and Mutated_model_C have mostly similar kinds of flexibility as compared to the Reference model.

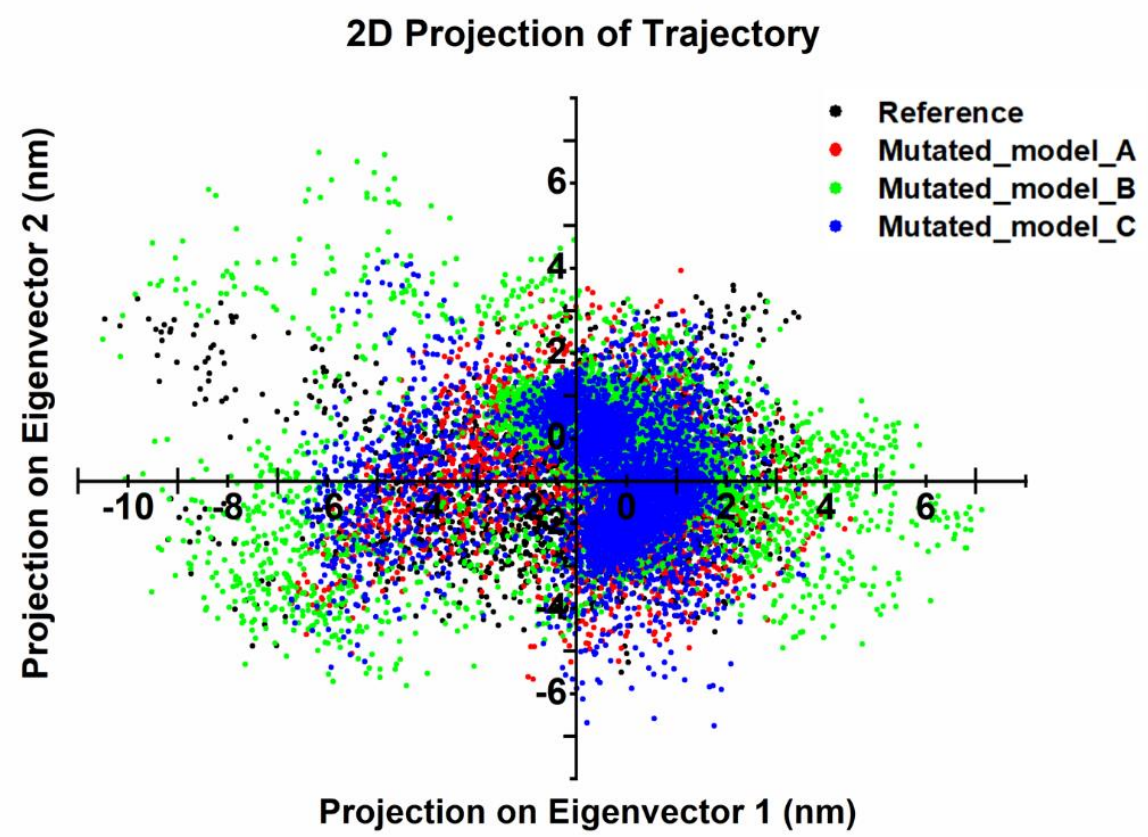


Figure 6. Projection of motion of ACE2 receptor docked with all four different modelled SARS-CoV-2 spike protein RBD region on PC1 and PC2. S protein from Wuhan Hu1 isolate, $S$ protein containing double mutations G476S and V483A, S protein containing single mutation G476S, and $S$ protein containing mutation V483A referred as Reference, Mutated_model_A, Mutated_model_B, and Mutated_model_C respectively.
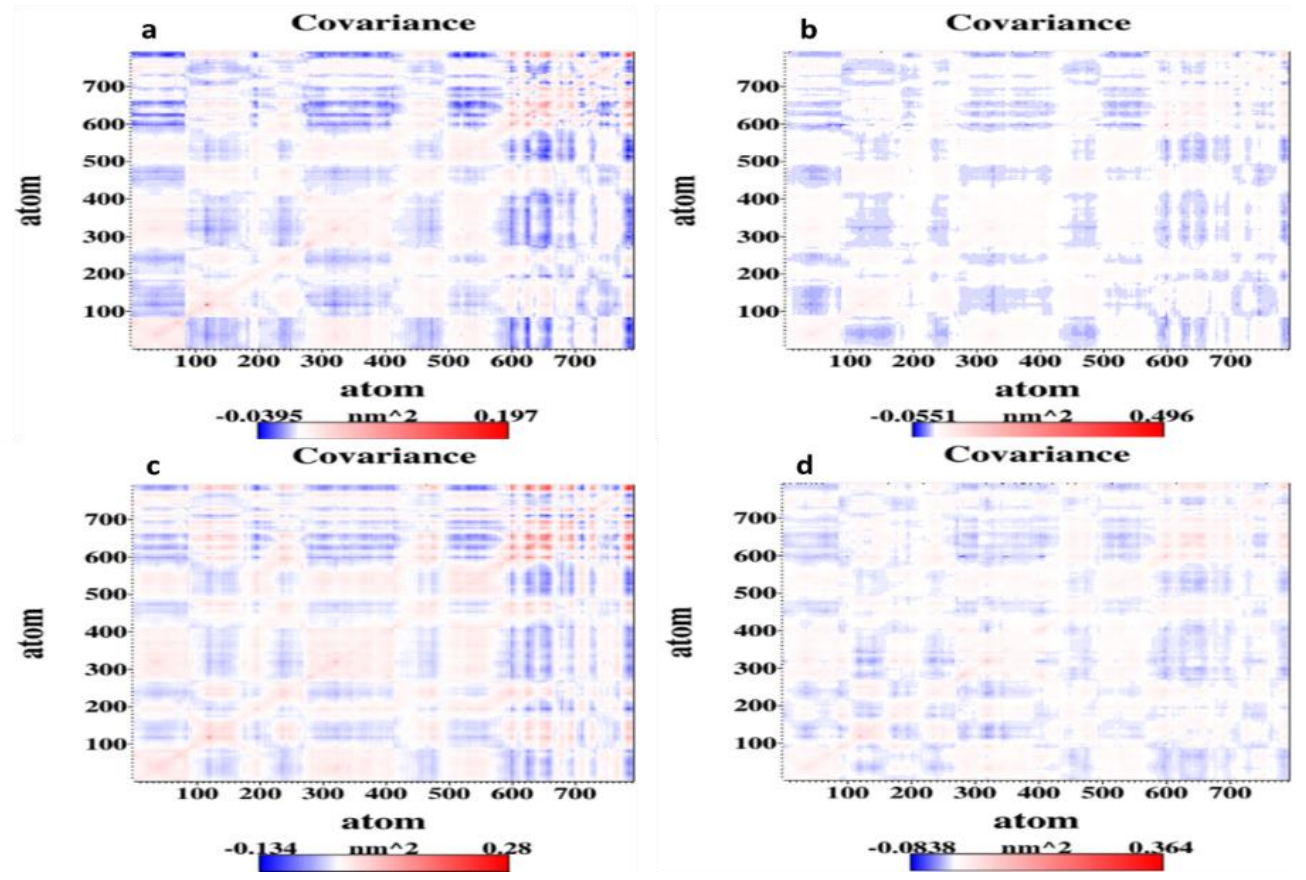

Figure 7. The diagonalized covariance matrix of ACE2 receptor complexes docked with (a) Reference (Wuhan Hu-1 isolate S protein), (b) Mutated_model_A (S protein containing mutations G476S and V483A), (c) Mutated_model_B (S protein containing mutation G476S), (d) Mutated_model_C (S protein containing mutation V483A). 


\section{Free Energy Analysis}

Gibbs free energy $(G)$ landscape (FEL) plot for ACE2 receptor complexes with all four different modelled SARS-CoV-2 spike protein RBD region have been generated using PC1 and PC2 coordinates. The G values are 8.77, 9.35, 11.3, and $12.4 \mathrm{~kJ} / \mathrm{mol}$ for the ACE2 receptor complex with Mutated_model_C, Mutated_model_A, Mutated_model_B, and Reference model respectively. The blue, cyan, and green regions in the plot signify a low energy state with highly stable structural conformation while the red region denotes high energy conformation. It has been observed that a smaller and more clustered blue minimal energy area in ACE2 receptor complexes docked with Mutated_model_C and Mutated_model_A as compared to Reference and Mutated_model_B (Fig.8).
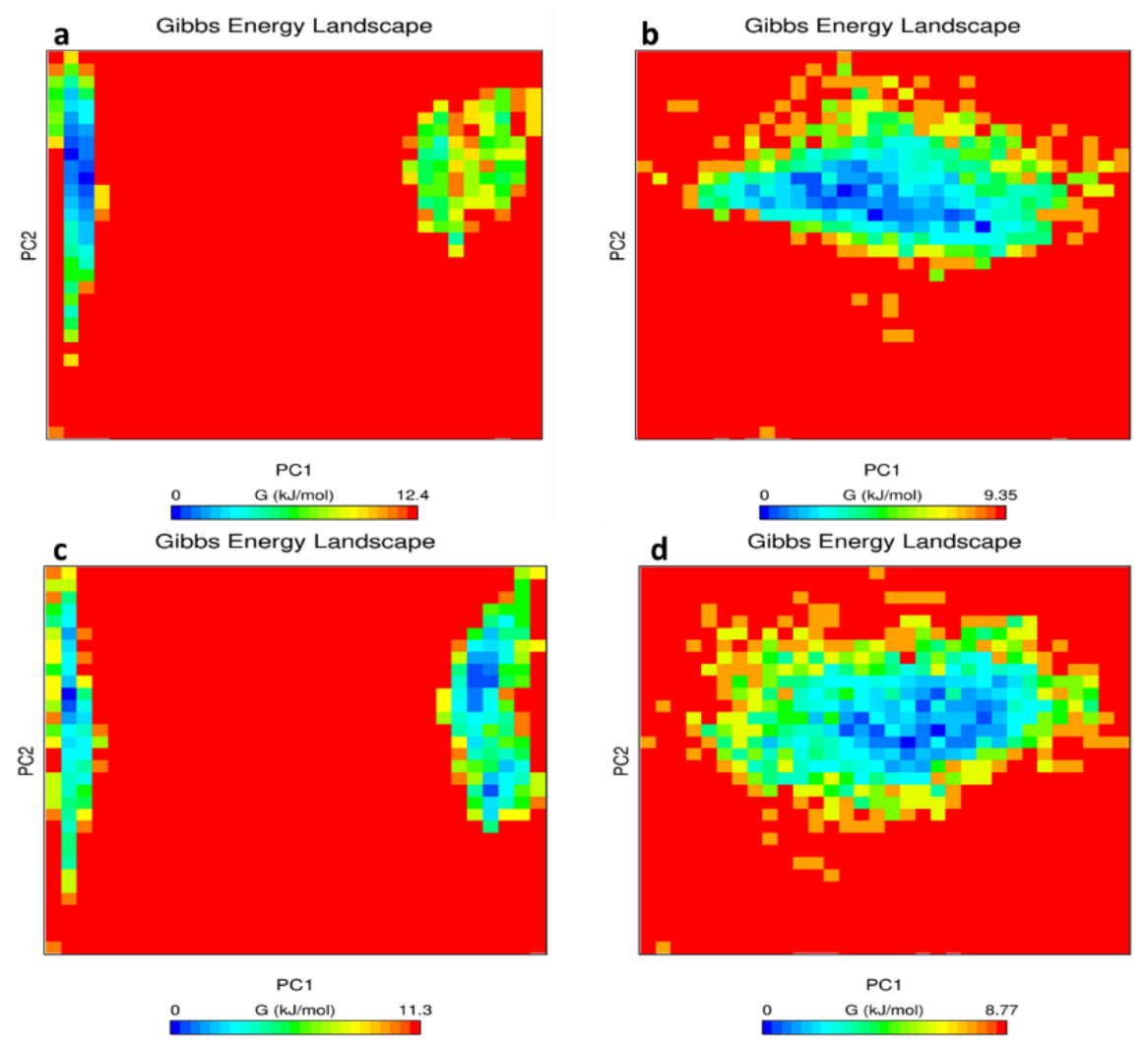

Figure 8. The Gibbs free energy landscape plot of ACE2 receptor complexes with (a) Reference (Reference or Wuhan Hu-1 isolate S protein), (b) Mutated_model_A (S protein containing mutations G476S and V483A), (c) Mutated_model_B (S protein containing single mutation G476S), and (d) Mutated_model_C (S protein containing single mutation V483A). 


\section{Secondary Structural Analysis during Simulation}

A broad range of studies has been conducted to investigate structural changes of ACE2 receptor complexes docked with four different modelled SARS-CoV2 spike protein RBD region during the $20 \mathrm{~ns}$ simulation. Moreover, how the four different modelled SARS-CoV-2 spike proteins are sticking to the ACE2 receptor, are a crucial point to understand the stability of the docked complexes. Four snapshots from every MD simulation trajectory of four protein-protein complexes have been extracted at every $5 \mathrm{~ns}$ interval ( $5 \mathrm{~ns}, 10 \mathrm{~ns}, 15 \mathrm{~ns}$, and $20 \mathrm{~ns}$ ). It has been found that all the four protein-protein complexes of ACE2 receptor and modelled SARS-CoV-2 spike protein RBD region are constantly attached to their interaction site throughout the whole simulation and there is no significant amount of structural change (Fig. 9).

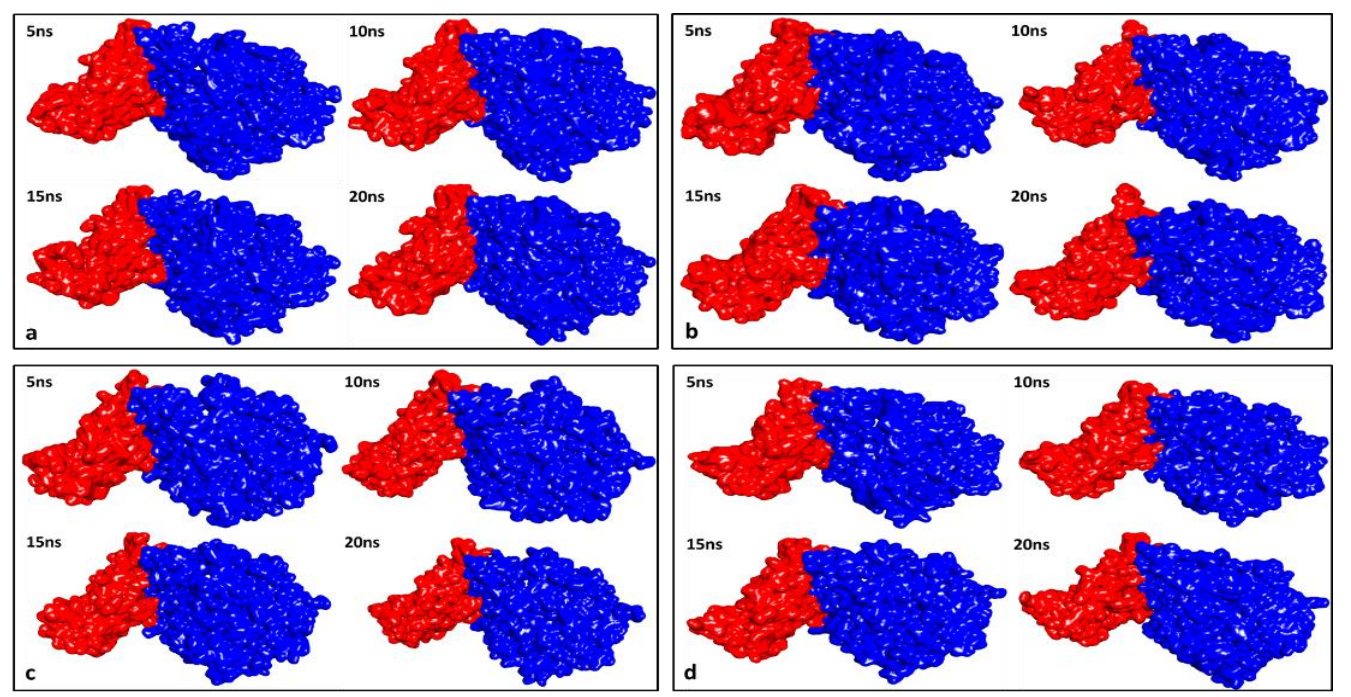

Figure 9. The snapshot of ACE2 receptor complexes docked with (a) Reference (Wuhan Hu-1 isolate S protein), (b) Mutated_model_A (S protein containing mutations G476S and V483A), (c) Mutated_model_B (S protein containing mutation G476S), and (d) Mutated_model_C (S protein containing mutations V483A). 
The Secondary structural analysis has shown no significant level of overall conformational change in four protein-protein complexes of ACE2 receptor and modelled SARS CoV-2 spike protein RBD region throughout the whole simulation (Fig.10 and Table 3).
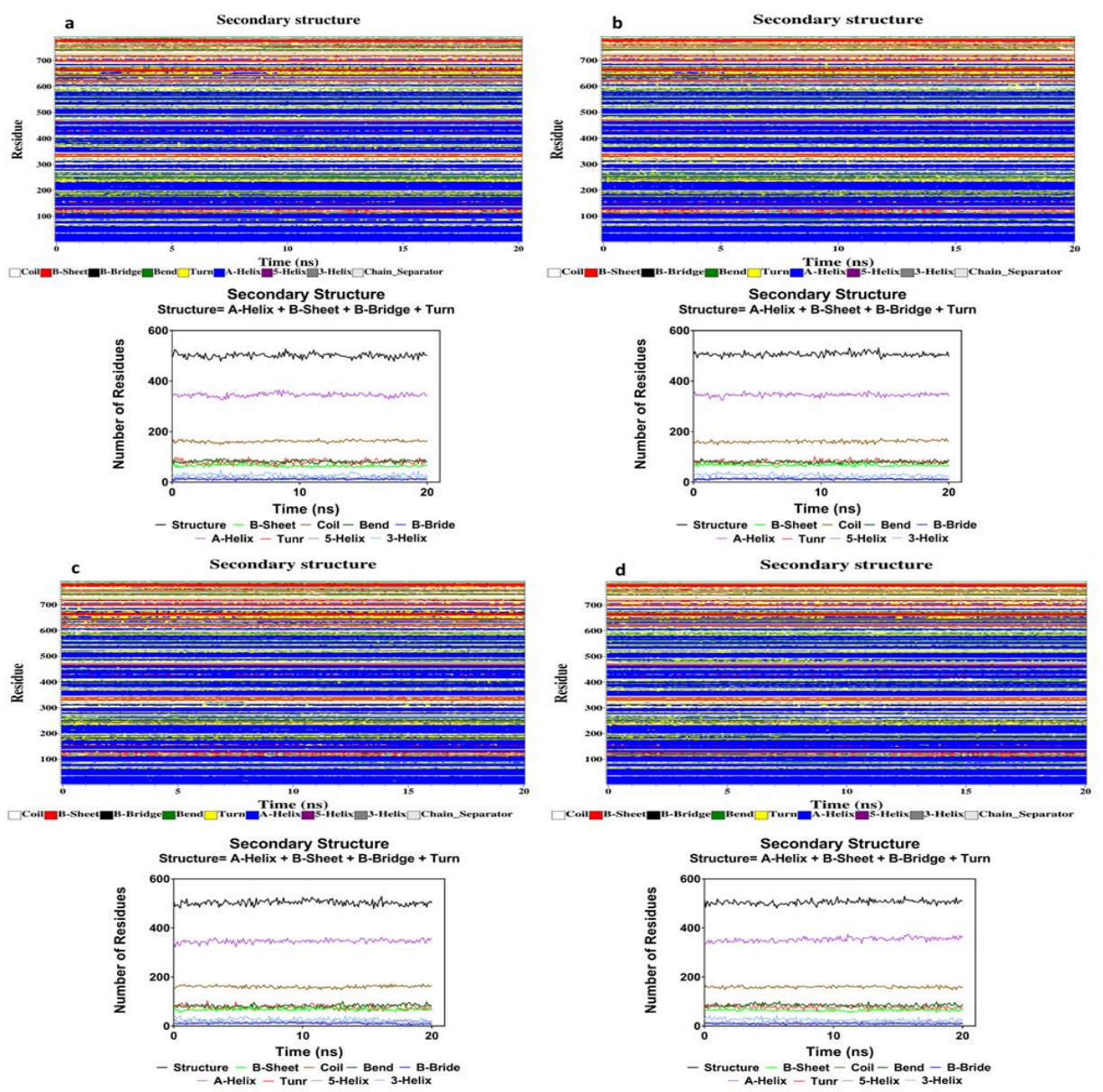

Figure 10. The secondary structure content of ACE2 receptor complexes with (a) Reference (Wuhan Hu-1 isolate S protein), (b) Mutated_model_A (S protein containing mutations G476S and V483A), (c) Mutated_model_B (S protein containing mutation G476S), and (d) Mutated_model_C (S protein containing mutation V483A). Residue index 1-597 represents the ACE2 receptor and 598-791 represents the SARS-CoV-2 spike protein RBD region. 
Table 3. The overall percentage of Secondary Structure Elements in SARS-CoV-2 Spike protein-ACE2 receptor protein complex

\begin{tabular}{|c|c|c|c|c|c|c|c|c|c|}
\hline $\begin{array}{c}\text { Complex with } \\
\text { ACE2 receptor } \\
\text { protein }\end{array}$ & $\begin{array}{c}\text { Structure } \\
\% \\
\text { A-Helix } \\
+ \text { B-Sheet } \\
+ \text { B-Bridge } \\
+ \text { Turn }\end{array}$ & Coil\% & $\begin{array}{c}\text { B- } \\
\text { Sheet } \\
\%\end{array}$ & $\begin{array}{c}\text { B- } \\
\text { Bridge } \\
\%\end{array}$ & $\begin{array}{c}\text { Bend } \\
\%\end{array}$ & $\begin{array}{c}\text { Turn } \\
\%\end{array}$ & $\begin{array}{c}\text { A- } \\
\text { Helix\% }\end{array}$ & $\begin{array}{c}\text { 5- } \\
\text { Helix } \\
\%\end{array}$ & $\begin{array}{c}\text { 3- } \\
\text { Helix } \\
\%\end{array}$ \\
\hline Reference & 63 & 20 & 8 & 1 & 10 & 10 & 44 & 2 & 3 \\
\hline $\begin{array}{c}\text { Mutated_model_A } \\
\text { (S476S and } \\
\text { V483A) }\end{array}$ & 64 & 20 & 9 & 2 & 10 & 10 & 44 & 2 & 3 \\
\hline $\begin{array}{c}\text { Mutated_model_B } \\
\text { (S476S) }\end{array}$ & 64 & 20 & 9 & 1 & 10 & 10 & 44 & 2 & 3 \\
\hline $\begin{array}{c}\text { Mutated_model_C } \\
\text { (V483A) }\end{array}$ & 64 & 20 & 8 & 1 & 11 & 10 & 45 & 2 & 3 \\
\hline
\end{tabular}




\section{Spike protein mutations lie in immunodominant antibody epitope}

Spike protein has shown high antigenic potentials in case of SARS previously. Thus, we tried to evaluate whether these mutations could hinder with the immunogenicity of the Spike protein. We first predicted presumptive antigenic peptide within the Spike protein with the help of online B cell epitope prediction tool. 60 peptides were predicted in the spike protein were included in the analysis of B cell epitopes with a more stringent $99.5 \%$ threshold for distance threshold value taking 0.350. Results showed though a peptide sequence with the antigenic properties falls.

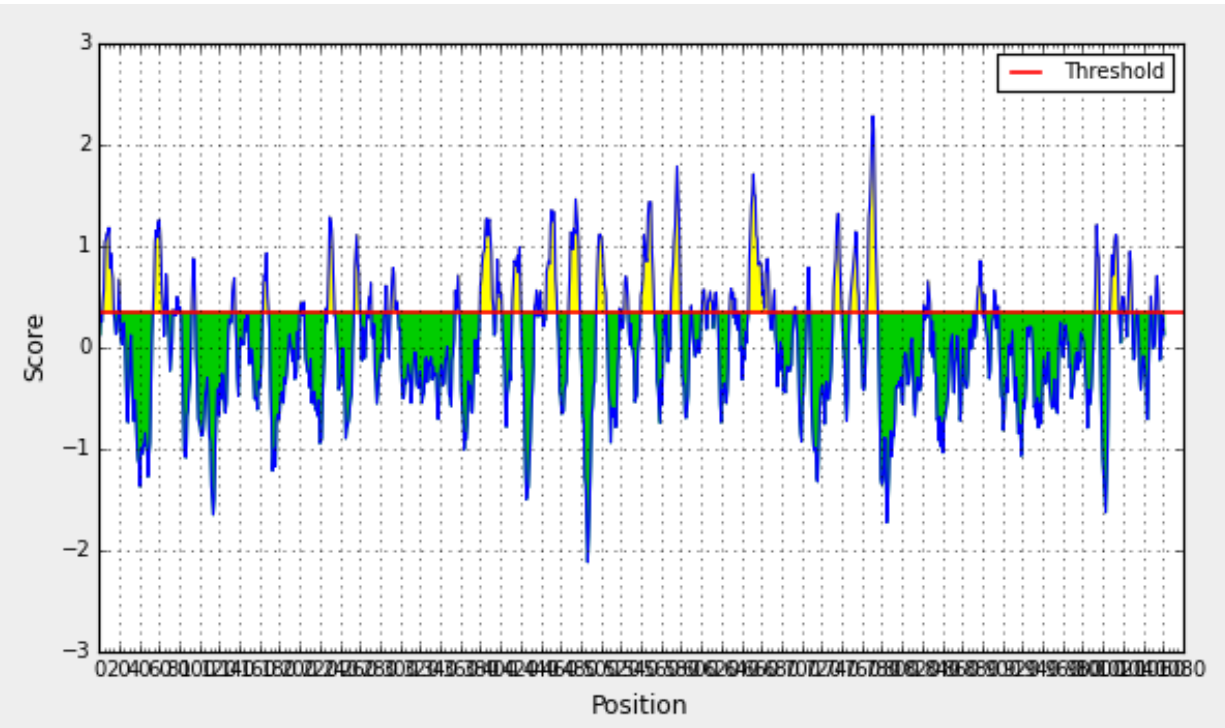

Figure 11: Peptide prediction with the amino acid scores in the spike protein. Green color indicates the negative values and yellow indicates the positive values with the red as the threshold.

Interestingly the epitope prediction showed antigenic peptides STEIYQAGS and NQVAVLYQDVNCTEVPVAIHADQ where G476S and D614G mutations lie respectively (Fig. 11)(Suppl. Table 4). 


\section{Discussion}

COVID-19 has become a major humanitarian catastrophe. The pathogenic SARS-CoV-2 has already claimed more than 300,000 lives within a short span 4 months across the globe since from its emergence and the current increasing cases in each passing days already alarmed a threat to global health emergency. The pathogenic SARS-CoV-2 uses RBD of spike (S) protein to attach with human ACE2, followed by priming and cleavage at S1/S2 site by the proteases for fusion of virus and host cell membrane. These consequently led to entry of the virus to host cell and pathogenesis of the disease. To understand and characterize the role of spike protein and arising intra-species (human) natural acquired mutations, here we studied SARSCoV-2 spike protein mutations from different parts of the world.

There are nine different mutations in the spike protein (Table 2, Suppl. Table 3) among them 2 mutations fall directly within the RBD region. We modeled these mutations and run simulations to study the effects of these mutations in binding with the ACE2 receptor. We found G476S mutation leads to enhance binding affinity towards the ACE2 receptor. The closet residue of ACE2 to S476 is Ser-19 (S19), which forms a hydrogen bond with the A475 residue juxtaposed to S476 (Fig. 5b). This interaction results in more stringent binding of the mutated spike protein with ACE2 receptor, which may lead to increase host cell entry.

Initial molecular docking study reveals that mutations in the SARS-CoV-2 spike protein RBD region are affecting the binding affinity of the ACE2 receptor and SARSCoV-2 spike protein $\mathrm{RBD}$ region. From molecular docking results, we found that Mutated_model_B (G476S) has a higher and Mutated_model_C (V483A) has lower binding affinity towards the ACE2 receptor as compared to Reference (Table 2). But when molecular dynamics simulation studies have been performed, we have found that Mutated_model_C (V483A) and Mutated_model_A(G476S and V483A) respectively have stronger non-bonded interaction energy when they interact with the ACE2 receptor as compared to Reference (Fig. 5d). Here, we also have found that in dynamic system Mutated_model_B (G476S) has a similar kind of interaction energy with the ACE2 receptor as compared to Reference. Such kinds of contradiction in results from molecular docking and MD simulation study may be due to the dynamic behaviour of molecules present in the MD simulation system. We found that Mutated_model_C, Mutated_model_A respectively have formed a higher number of $\mathrm{H}$-bonds with the ACE2 receptor as compared to Reference and Mutated_model_B 
throughout the whole MD simulation (Fig. 5e). As $\mathrm{H}$-bond is known to stabilize the interaction between two molecules, it may be due to that Mutated_model_C and Mutated_model_A interact more stably and strongly with the ACE2 receptor as compared to Reference and Mutated_model_B. Regarding that, the structural stability of ACE2 receptor complexes docked with Mutated_model_C and Mutated_model_A have been further validated by principal component analysis (Fig. 6 and 7) and free energy landscape (Fig. 8). Overall, in-silico study indicates that V483A and/or G476S in the SARS-CoV-2 spike protein RBD region can enhance its interaction with ACE2 receptor, which can increase the binding of SARS-CoV-2 virus with human cells presenting ACE2 receptor. ACE2 receptor is widely expressed in epithelial cell lining the nasal cavity and lung alveoli ${ }^{18}$. Findings of this study reveal the regional variation of the spike protein mutations and their presumptive effects on the disease spread and severity.

Mutations harboring in the spike protein affecting the immunogenicity of the virus is of particular concern while designing a therapeutics or vaccine. Considering this here we sought to predict the effect of observed mutations in determining antigenicity or epitope recognization. We found G476S and D614G mutations lie in predicted antigenic B cell epitope (Table 4) consistent with the previous report of SARS-CoV antigenicity ${ }^{19}$. A recent study reported monoclonal antibody against RBD region of Spike protein, inhibit SARS-CoV2 infection ${ }^{20}$. Specifically, D614 resides in an immunodominant peptide, recognized by antibodies from convalescent SARS patients ${ }^{19}$. G476S, D614G mutations might hinder with this protective G476 and D614 directed antibody response. Interestingly Antibody dependent enhancement (ADE) of the SARS-CoV infection by antibodies against S597-625 region besides the neutralizing antibodies against this region had also been reported ${ }^{19}$. D614G mutation might facilitate the ADE response. Though it is difficult to predict which of the role D614G mutation would play but certainly conducive in spreading infection of the virus, which is evident from the fact that D614G mutation represents the highest frequency of mutations found in the spike protein of the SARS-CoV-2 of different regions in the world.

$S$ protein cleavage at the $\mathrm{S} 1 / \mathrm{S} 2$ boundary is absolutely necessary for viral entry. D614 lies near the S1/S2 boundary and D614G mutation introduce a new cleavage site specific for a serine protease, elastase. Introduction of this new cleavage 
site apart from the already available TMPRSS2 and furin cleavage site ${ }^{9,15}$ confers SARS-CoV2 a broader tropism and enhance transmissibility.

These mutations are needed to be studied more extensively and thoroughly to ascertain the implications of the mutations in the infectivity in COVID-19. This study will not only help in understanding the arising variation but also help in better designing of the vaccine against SARCoV2

\section{Material and Methods}

\section{Data collection and sequence analysis}

SARS-CoV2, SARS-CoV, MERS-CoV, Bat-CoV RaTG13, Pangolin-CoV genome sequences were downloaded from NCBI Virus genome database (Supplementary Table 1). All assembled SARS-CoV-2 FASTA query sequences were analyzed and aligned against the Wuhan, SARS-CoV2 reference sequence (NC_004718.3) using NCBI public interface Basic Local Alignment Search Tool (BLAST) or using CLUSTALW algorithm in MEGA X. Phylogenetic analysis was performed in MEGA X.

\section{Homology modeling of SARS-CoV-2 spike protein}

The SARS-CoV-2 surface glycoprotein/spike protein (GeneBank: MN908947) structure has been modeled using the Phyre2 ${ }^{21}$. The FASTA protein sequence has been uploaded to the Phyre 2 interface and run with the template ( $c 5 \times 5 b B$ ) being SARS-CoV spike glycoprotein, (PDB: 5X5B, Chain B). Later on, structural validation of the modelled protein has been performed by the RMSD value and Ramachandran plot ${ }^{22}$.

\section{Mutants SARS-CoV-2 spike modelling and simulation}

Mutations in modeled SAR-CoV-2 spike protein have been performed using the MDWeb tool ${ }^{23}$.

Molecular docking study of SARS-CoV-2 spike protein and Angiotensin-converting enzyme 2 (ACE2) receptor

Protein-Protein docking studies of SARS-CoV-2 spike protein and ACE2 have been performed using the HDOCK server ${ }^{24}$. Later on, Biovia Discovery Studio 2017R2 
25 and LigPlot $^{+} 2619191$ have been used for visualization and analysis purpose of docking related results.

\section{Molecular dynamics simulation}

Stability, flexibility, and non-bonded interaction energy of ACE2 receptor complexes docked with four different modelled SARS-CoV-2 spike protein RBD region are investigated through explicit solvent molecular dynamics (MD) simulation study. Gromacs 2019.4 package has been used to run and analyse 20 ns MD simulation following the Gromacs tutorial protocols (27). For this purpose charmm27 force field has been used to generate topology files.

\section{Immunogenicity analysis of Spike Protein}

Immunogenicity of the spike protein of SARS-CoV-2 was predicted using Tools of immunomedicine tool group and with DiscTope2. All the antigenic peptides chart and also the peptide scores and B cell epitope prediction are studied and subsequently with retrieved graph are been retrieved accordingly. The substitution matrix BLOSUM 62 is considered.

\section{Contribution:}

Sarkar S, Mandal M and Srivastava A designed the initial study. Sarkar S, Chakraborty $S$ contributed the genomic data mining and mutational analysis. Bioinformatics related to homology modeling, extensive docking and simulation analyses were done by Saha $\mathrm{P}$, and Majumdar R. All the authors analyzed the final data and approved the final version.

\section{Declaration of Competing Interest:}

No authors have competing interests in this research.

\section{Acknowledgements:}

Saha $P$ is the recipient of Department of Biotechnology (DBT). Chakraborty $S$ is the recipient of Council of Scientific and Industrial Research (CSIR) Junior Research Fellowship (JRF). Majumder $\mathrm{R}$ is the recipient of Fellowship from Indian Institute of Technology Khargpur and Dr. Mandal M is the recipient of $\mathrm{J} \mathrm{C} \mathrm{Bose} \mathrm{Fellowship} \mathrm{(DST,}$ India). The authors would like to acknowledge the funding of Science \& Engineering 
Research Board, Indian Council of Medical Research and CSIR for providing structural and financial support.

\section{References}

1. Guan, W. J.; Ni, Z. Y.; Hu, Y.; Liang, W. H.; Ou, C. Q.; He, J. X.; Liu, L.; Shan, H.; Lei, C. L.; Hui, D. S. C.; Du, B.; Li, L. J.; Zeng, G.; Yuen, K. Y.; Chen, R. C.; Tang, C. L.; Wang, T.; Chen, P. Y.; Xiang, J.; Li, S. Y.; Wang, J. L.; Liang, Z. J.; Peng, Y. X.; Wei, L.; Liu, Y.; Hu, Y. H.; Peng, P.; Wang, J. M.; Liu, J. Y.; Chen, Z.; Li, G.; Zheng, Z. J.; Qiu, S. Q.; Luo, J.; Ye, C. J.; Zhu, S. Y.; Zhong, N. S.; China Medical Treatment Expert Group for, C., Clinical Characteristics of Coronavirus Disease 2019 in China. N Engl J Med 2020, 382 (18), 1708-1720.

2. Zhou, P.; Yang, X. L.; Wang, X. G.; Hu, B.; Zhang, L.; Zhang, W.; Si, H. R.; Zhu, Y.; Li, B.; Huang, C. L.; Chen, H. D.; Chen, J.; Luo, Y.; Guo, H.; Jiang, R. D.; Liu, M. Q.; Chen, Y.; Shen, X. R.; Wang, X.; Zheng, X. S.; Zhao, K.; Chen, Q. J.; Deng, F.; Liu, L. L.; Yan, B.; Zhan, F. X.; Wang, Y. Y.; Xiao, G. F.; Shi, Z. L., A pneumonia outbreak associated with a new coronavirus of probable bat origin. Nature 2020, 579 (7798), 270-273.

3. WHO Coronavirus disease (COVID-2019) situation reports. https://www.who.int/emergencies/diseases/novel-coronavirus-2019.

4. Drosten, C.; Gunther, S.; Preiser, W.; van der Werf, S.; Brodt, H. R.; Becker, S.; Rabenau, H.; Panning, M.; Kolesnikova, L.; Fouchier, R. A.; Berger, A.; Burguiere, A. M.; Cinatl, J.; Eickmann, M.; Escriou, N.; Grywna, K.; Kramme, S.; Manuguerra, J. C.; Muller, S.; Rickerts, V.; Sturmer, M.; Vieth, S.; Klenk, H. D.; Osterhaus, A. D.; Schmitz, H.; Doerr, H. W., Identification of a novel coronavirus in patients with severe acute respiratory syndrome. N Engl J Med 2003, 348 (20), 1967-76.

5. Zaki, A. M.; van Boheemen, S.; Bestebroer, T. M.; Osterhaus, A. D.; Fouchier, R. A., Isolation of a novel coronavirus from a man with pneumonia in Saudi Arabia. $N$ Engl J Med 2012, 367 (19), 1814-20.

6. Li, W.; Shi, Z.; Yu, M.; Ren, W.; Smith, C.; Epstein, J. H.; Wang, H.; Crameri, G.; Hu, Z.; Zhang, H.; Zhang, J.; McEachern, J.; Field, H.; Daszak, P.; Eaton, B. T.; Zhang, S.; Wang, L. F., Bats are natural reservoirs of SARS-like coronaviruses. Science 2005, 310 (5748), 676-9.

7. Ge, X. Y.; Li, J. L.; Yang, X. L.; Chmura, A. A.; Zhu, G.; Epstein, J. H.; Mazet, J. K.; Hu, B.; Zhang, W.; Peng, C.; Zhang, Y. J.; Luo, C. M.; Tan, B.; Wang, N.; Zhu, Y.; Crameri, G.; Zhang, S. Y.; Wang, L. F.; Daszak, P.; Shi, Z. L., Isolation and characterization of a bat SARS-like coronavirus that uses the ACE2 receptor. Nature 2013, 503 (7477), 535-8.

8. Memish, Z. A.; Mishra, N.; Olival, K. J.; Fagbo, S. F.; Kapoor, V.; Epstein, J. H.; Alhakeem, R.; Durosinloun, A.; Al Asmari, M.; Islam, A.; Kapoor, A.; Briese, T.; 
Daszak, P.; Al Rabeeah, A. A.; Lipkin, W. I., Middle East respiratory syndrome coronavirus in bats, Saudi Arabia. Emerg Infect Dis 2013, 19 (11), 1819-23.

9. Walls, A. C.; Park, Y. J.; Tortorici, M. A.; Wall, A.; McGuire, A. T.; Veesler, D., Structure, Function, and Antigenicity of the SARS-CoV-2 Spike Glycoprotein. Cell 2020, 181 (2), 281-292 e6.

10. Tortorici, M. A.; Veesler, D., Structural insights into coronavirus entry. Adv Virus Res 2019, 105, 93-116.

11. Li, F.; Li, W.; Farzan, M.; Harrison, S. C., Structure of SARS coronavirus spike receptor-binding domain complexed with receptor. Science 2005, 309 (5742), 1864-8.

12. Wang, Q.; Zhang, Y.; Wu, L.; Niu, S.; Song, C.; Zhang, Z.; Lu, G.; Qiao, C.; Hu, Y.; Yuen, K. Y.; Wang, Q.; Zhou, H.; Yan, J.; Qi, J., Structural and Functional Basis of SARS-CoV-2 Entry by Using Human ACE2. Cell 2020.

13. Wan, Y.; Shang, J.; Graham, R.; Baric, R. S.; Li, F., Receptor Recognition by the Novel Coronavirus from Wuhan: an Analysis Based on Decade-Long Structural Studies of SARS Coronavirus. J Virol 2020, 94 (7).

14. Glowacka, I.; Bertram, S.; Muller, M. A.; Allen, P.; Soilleux, E.; Pfefferle, S.; Steffen, I.; Tsegaye, T. S.; He, Y.; Gnirss, K.; Niemeyer, D.; Schneider, H.; Drosten, C.; Pohlmann, S., Evidence that TMPRSS2 activates the severe acute respiratory syndrome coronavirus spike protein for membrane fusion and reduces viral control by the humoral immune response. J Virol 2011, 85 (9), 4122-34.

15. Hoffmann, M.; Kleine-Weber, H.; Schroeder, S.; Kruger, N.; Herrler, T.; Erichsen, S.; Schiergens, T. S.; Herrler, G.; Wu, N. H.; Nitsche, A.; Muller, M. A.; Drosten, C.; Pohlmann, S., SARS-CoV-2 Cell Entry Depends on ACE2 and TMPRSS2 and Is Blocked by a Clinically Proven Protease Inhibitor. Cell 2020, 181 (2), 271-280 e8.

16. Liu, W.; Fontanet, A.; Zhang, P. H.; Zhan, L.; Xin, Z. T.; Baril, L.; Tang, F.; Lv, H.; Cao, W. C., Two-year prospective study of the humoral immune response of patients with severe acute respiratory syndrome. J Infect Dis 2006, 193 (6), 792-5.

17. Lan, J.; Ge, J.; Yu, J.; Shan, S.; Zhou, H.; Fan, S.; Zhang, Q.; Shi, X.; Wang, Q.; Zhang, L.; Wang, X., Structure of the SARS-CoV-2 spike receptor-binding domain bound to the ACE2 receptor. Nature 2020.

18. Sungnak, W.; Huang, N.; Becavin, C.; Berg, M.; Queen, R.; Litvinukova, M.; Talavera-Lopez, C.; Maatz, H.; Reichart, D.; Sampaziotis, F.; Worlock, K. B.; Yoshida, M.; Barnes, J. L.; Network, H. C. A. L. B., SARS-CoV-2 entry factors are highly expressed in nasal epithelial cells together with innate immune genes. Nat Med 2020, $26(5), 681-687$. 
19. Wang, Q.; Zhang, L.; Kuwahara, K.; Li, L.; Liu, Z.; Li, T.; Zhu, H.; Liu, J.; Xu, Y.; Xie, J.; Morioka, H.; Sakaguchi, N.; Qin, C.; Liu, G., Immunodominant SARS Coronavirus Epitopes in Humans Elicited both Enhancing and Neutralizing Effects on Infection in Non-human Primates. ACS Infect Dis 2016, 2 (5), 361-76.

20. Wang, C.; Li, W.; Drabek, D.; Okba, N. M. A.; van Haperen, R.; Osterhaus, A.; van Kuppeveld, F. J. M.; Haagmans, B. L.; Grosveld, F.; Bosch, B. J., A human monoclonal antibody blocking SARS-CoV-2 infection. Nat Commun 2020, 11 (1), 2251.

21. Kelley, L. A.; Mezulis, S.; Yates, C. M.; Wass, M. N.; Sternberg, M. J., The Phyre2 web portal for protein modeling, prediction and analysis. Nat Protoc 2015, 10 (6), 845-58.

22. Lovell, S. C.; Davis, I. W.; Arendall, W. B., 3rd; de Bakker, P. I.; Word, J. M.; Prisant, M. G.; Richardson, J. S.; Richardson, D. C., Structure validation by Calpha geometry: phi,psi and Cbeta deviation. Proteins 2003, 50 (3), 437-50.

23. Hospital, A.; Andrio, P.; Fenollosa, C.; Cicin-Sain, D.; Orozco, M.; Gelpi, J. L., MDWeb and MDMoby: an integrated web-based platform for molecular dynamics simulations. Bioinformatics 2012, 28 (9), 1278-9.

24. Yan, Y.; Tao, H.; He, J.; Huang, S. Y., The HDOCK server for integrated protein-protein docking. Nat Protoc 2020, 15 (5), 1829-1852.

25. Dassault Systèmes BIOVIA, B. D. S., DS Visualizer. 2017, Discovery Studio (2017R2).

26. Wallace, A. C.; Laskowski, R. A.; Thornton, J. M., LIGPLOT: a program to generate schematic diagrams of protein-ligand interactions. Protein Eng 1995, 8 (2), 127-34. 


\section{Supplementary Table 1: Sequence identity using Mega BLAST}

\begin{tabular}{|c|c|c|c|c|c|c|}
\hline Species & $\begin{array}{l}\text { Max } \\
\text { Score }\end{array}$ & $\begin{array}{l}\text { Total } \\
\text { Score }\end{array}$ & $\begin{array}{l}\text { Query } \\
\text { cover }\end{array}$ & $\begin{array}{l}\mathrm{E} \\
\text { value }\end{array}$ & $\begin{array}{l}\text { Percentage } \\
\text { Identity }\end{array}$ & Accession \\
\hline $\begin{array}{l}\text { Severe acute respiratory } \\
\text { syndrome coronavirus } 2\end{array}$ & 53927 & 53927 & $100 \%$ & 0.0 & 100.00 & MN908947.3 \\
\hline $\begin{array}{l}\text { Severe acute respiratory } \\
\text { syndrome coronavirus } 2 \text { isolate }\end{array}$ & 53927 & 53927 & $100 \%$ & 0.0 & 100.00 & NC_045512.2 \\
\hline $\begin{array}{l}\text { Severe acute respiratory } \\
\text { syndrome coronavirus } 2 \text { isolate }\end{array}$ & 53876 & 53876 & $99 \%$ & 0.0 & 99.99 & MN985325.1 \\
\hline $\begin{array}{l}\text { Severe acute respiratory } \\
\text { syndrome coronavirus } 2 \text { isolate }\end{array}$ & 53849 & 53849 & $99 \%$ & 0.0 & 99.99 & MT066156.1 \\
\hline $\begin{array}{l}\text { Severe acute respiratory } \\
\text { syndrome coronavirus } 2 \text { isolate }\end{array}$ & 53806 & 53806 & $99 \%$ & 0.0 & 99.99 & MT050493.1 \\
\hline Bat coronavirus RaTG13 & 48640 & 48640 & $99 \%$ & 0.0 & 96.12 & MN996532.1 \\
\hline $\begin{array}{l}\text { Pangolin coronavirus isolate } \\
\text { PCoV_GX-P2V }\end{array}$ & 34136 & 34136 & $99 \%$ & 0.0 & 85.42 & MT072864.1 \\
\hline SARS coronavirus & 22291 & 26549 & $98 \%$ & 0.0 & 80.26 & NC_004718.3 \\
\hline $\begin{array}{l}\text { SARS coronavirus Urbani } \\
\text { isolate icSARS-C3 }\end{array}$ & 22192 & 26549 & $98 \%$ & 0.0 & 80.18 & MK062181.1 \\
\hline $\begin{array}{l}\text { SARS coronavirus Urbani } \\
\text { isolate icSARS-C3-MA }\end{array}$ & 22174 & 26361 & $98 \%$ & 0.0 & 80.16 & MK062182.1 \\
\hline $\begin{array}{l}\text { SARS coronavirus Urbani } \\
\text { isolate icSARS-C7 }\end{array}$ & 20475 & 26322 & $98 \%$ & 0.0 & 79.94 & MK062183.1 \\
\hline $\begin{array}{l}\text { Pangolin coronavirus isolate } \\
\text { MP789 }\end{array}$ & 9768 & 34220 & $85 \%$ & 0.0 & 91.63 & MT084071.1 \\
\hline $\begin{array}{l}\text { MERS isolate Hu/Jeddah-KSA- } \\
\text { 173RS1570/2017 }\end{array}$ & 1885 & 2600 & $29 \%$ & 0.0 & 67.12 & MN723543.1 \\
\hline $\begin{array}{l}\text { MERS isolate Hu/Riyadh-KSA- } \\
\text { 039D3T/2016 }\end{array}$ & 1883 & 2589 & $29 \%$ & 0.0 & 67.09 & MG757604.1 \\
\hline $\begin{array}{l}\text { MERS isolate Hu/Riyadh-KSA- } \\
\text { 036D1N/2016 }\end{array}$ & 1881 & 2591 & $29 \%$ & 0.0 & 67.10 & MG757605.1 \\
\hline $\begin{array}{l}\text { MERS isolate Hu/Riyadh-KSA- } \\
\text { 031D1N/2015 }\end{array}$ & 1876 & 2653 & $29 \%$ & 0.0 & 67.09 & MG757603.1 \\
\hline$\beta$-coronavirus England 1 & 1872 & 2584 & $29 \%$ & 0.0 & 67.07 & NC_038294.1 \\
\hline
\end{tabular}


Supplementary Figures:

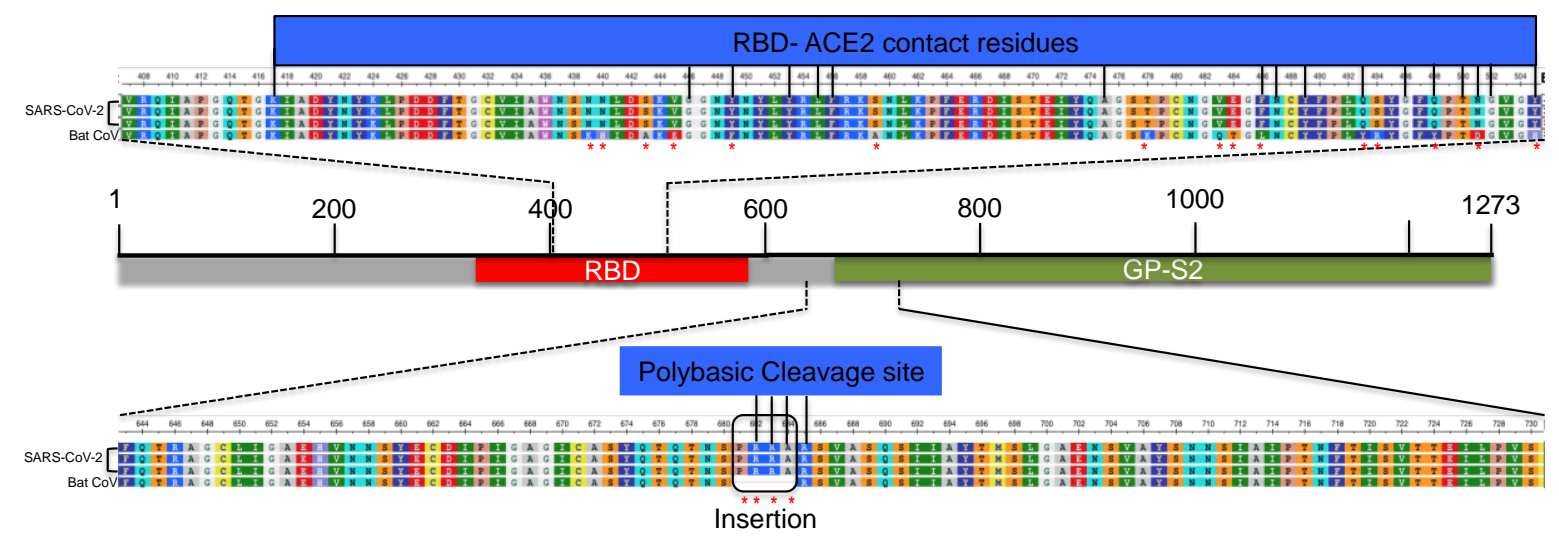

Supplementary Figure 1: Multiple sequence aligment showing amino acid compositional differences in S protein of SARS-CoV-2 and Bat-CoV . RBD domain showed higher compositional differences and furin/polybasic cleavage site is found in the periphery of S1/S2 region. 
Supplementary Table 2: BLAST analyses studying the similarity of nucleotide sequences in coding region

\begin{tabular}{|c|c|c|c|c|c|c|c|c|c|c|}
\hline $\begin{array}{l}\text { Coding } \\
\text { Gene }\end{array}$ & $\begin{array}{c}\% \\
\text { Identity }\end{array}$ & $\begin{array}{l}\text { Align } \\
\text { Len }\end{array}$ & $\begin{array}{c}\text { Mis- } \\
\text { matche } \\
\mathrm{s}\end{array}$ & $\begin{array}{c}\text { Gap } \\
\text { Opens }\end{array}$ & Start $^{*}$ & End $^{*}$ & $\begin{array}{c}\text { Start } \\
\#\end{array}$ & End\# & E-Value & $\begin{array}{c}\text { Bit } \\
\text { Score }\end{array}$ \\
\hline ORF1ab & 96.505 & 21290 & 741 & 1 & 266 & 21555 & 251 & 21537 & 0 & 35038 \\
\hline$S$ & 92.887 & 3824 & 256 & 3 & $\begin{array}{r}2156 \\
3\end{array}$ & 25384 & $\begin{array}{r}2154 \\
5\end{array}$ & 25354 & 0 & 5541 \\
\hline ORF3a & 96.256 & 828 & 31 & 0 & $\begin{array}{r}2539 \\
3\end{array}$ & 26220 & $\begin{array}{r}2536 \\
3\end{array}$ & 26190 & 0 & 1358 \\
\hline$E$ & 99.561 & 228 & 1 & 0 & $\begin{array}{r}2624 \\
5\end{array}$ & 26472 & $\begin{array}{r}2621 \\
5\end{array}$ & 26442 & $\begin{array}{r}1.86 \mathrm{E}- \\
116\end{array}$ & 407 \\
\hline$M$ & 95.516 & 669 & 27 & 1 & $\begin{array}{r}2652 \\
3\end{array}$ & 27191 & $\begin{array}{r}2649 \\
3\end{array}$ & 27158 & 0 & 1070 \\
\hline ORF6 & 98.387 & 186 & 3 & 0 & $\begin{array}{r}2720 \\
2\end{array}$ & 27387 & $\begin{array}{r}2716 \\
9\end{array}$ & 27354 & $9.48 \mathrm{E}-93$ & 327 \\
\hline ORF7a & 95.628 & 366 & 16 & 0 & $\begin{array}{r}2739 \\
4\end{array}$ & 27759 & $\begin{array}{r}2736 \\
0\end{array}$ & 27725 & $\begin{array}{r}8.06 \mathrm{E}- \\
171\end{array}$ & 588 \\
\hline ORF7b & 99.242 & 132 & 1 & 0 & $\begin{array}{r}2775 \\
6\end{array}$ & 27887 & $\begin{array}{r}2772 \\
2\end{array}$ & 27853 & $3.15 E-66$ & 239 \\
\hline ORF8 & 96.995 & 366 & 11 & 0 & $\begin{array}{r}2789 \\
4\end{array}$ & 28259 & $\begin{array}{r}2786 \\
0\end{array}$ & 28225 & $\begin{array}{r}3.70 \mathrm{E}- \\
179\end{array}$ & 616 \\
\hline $\mathrm{N}$ & 96.905 & 1260 & 39 & 0 & $\begin{array}{r}2827 \\
4\end{array}$ & 29533 & $\begin{array}{r}2824 \\
0\end{array}$ & 29499 & 0 & 2111 \\
\hline ORF10 & 99.145 & 117 & 1 & 0 & $\begin{array}{r}2955 \\
8\end{array}$ & 29674 & $\begin{array}{r}2952 \\
4\end{array}$ & 29640 & $6.00 \mathrm{E}-58$ & 211 \\
\hline
\end{tabular}

*NC_045512.2

\#MN996532.1 
Supplementary Table 3.

Excel File: Mutation_S_analysis.csv 
Supplementary Table 4: Table showing predicted peptides for B cell epitope prediction

\begin{tabular}{|c|c|c|c|}
\hline $\mathbf{n}$ & $\begin{array}{c}\text { Start } \\
\text { Position }\end{array}$ & Sequence & End Position \\
\hline 1 & 4 & FLVLLPLVSSQCVNL & 18 \\
\hline 2 & 22 & TQLPPAY & 28 \\
\hline 3 & 33 & TRGVYYPDKVFRSSVLHSTQDLFLPFFSNVTWFHAIHV & 70 \\
\hline 4 & 80 & DNPVLPFNDGVYFA & 93 \\
\hline 5 & 114 & TQSLLIV & 120 \\
\hline 6 & 122 & NATNVVIKVCEFQFCNDPFLGVYY & 145 \\
\hline 7 & 156 & EFRVYSS & 162 \\
\hline 8 & 167 & TFEYVSQPFLM & 177 \\
\hline 9 & 199 & GYFKIYSK & 206 \\
\hline 10 & 208 & TPINLVRDLPQGFSALEPLVDLPIG & 232 \\
\hline 11 & 237 & RFQTLLALHRSYLT & 250 \\
\hline 12 & 261 & GAAAYYVGYLQPRTFLL & 277 \\
\hline 13 & 285 & ITDAVDCALDP & 295 \\
\hline 14 & 297 & SETKCTLKSFTVEK & 310 \\
\hline 15 & 316 & SNFRVQPTESIVRF & 329 \\
\hline 16 & 331 & NITNLCPFGE & 340 \\
\hline 17 & 346 & RFASVYA & 352 \\
\hline 18 & 357 & RISNCVADYSVLYNS & 371 \\
\hline 19 & 373 & SFSTFKCYGVSP & 384 \\
\hline 20 & 386 & KLNDLCFTNVYADSFVIR & 403 \\
\hline 21 & 428 & DFTGCVIA & 435 \\
\hline 22 & 449 & YNYLYRL & 455 \\
\hline 23 & 469 & STEIYQAGS & 477 \\
\hline 24 & 484 & EGFNCYFPLQSYG & 496 \\
\hline 25 & 503 & VGYQPYRVVVLSFELLHAPATVCGP & 527 \\
\hline 26 & 534 & VKNKCVN & 540 \\
\hline 27 & 547 & TGTGVLT & 553 \\
\hline 28 & 557 & KKFLPFQ & 563 \\
\hline 29 & 580 & QTLEILDITPCSFGGVSVIT & 599 \\
\hline 30 & 606 & NQVAVLYQDVNCTEVPVAIHADQ & 628 \\
\hline
\end{tabular}




\begin{tabular}{|c|c|c|c|}
\hline 31 & 631 & PTWRVYSTGSNVFQTRAGCLIGA & 653 \\
\hline 32 & 660 & YECDIPIGAGICASY & 674 \\
\hline 33 & 683 & RARSVASQSIIAYTM & 697 \\
\hline 34 & 701 & AENSVAY & 707 \\
\hline 35 & 718 & FTISVTTEILPVS & 730 \\
\hline 36 & 734 & TSVDCTMYICGD & 745 \\
\hline 37 & 748 & ECSNLLLQYGSFCTQLN & 764 \\
\hline 38 & 779 & QEVFAQVKQIYKT & 791 \\
\hline 39 & 801 & NFSQILPDP & 809 \\
\hline 40 & 817 & FIEDLLFNKVTLADA & 831 \\
\hline 41 & 833 & FIKQYGDCLGD & 843 \\
\hline 42 & 845 & AARDLICAQ & 853 \\
\hline 43 & 856 & NGLTVLPPLLT & 866 \\
\hline 44 & 871 & AQYTSALLAG & 880 \\
\hline 45 & 890 & AGAALQIPF & 898 \\
\hline 46 & 911 & VTQNVLYENQ & 920 \\
\hline 47 & 931 & IGKIQDSLSSTASALGKLQDVVNQ & 954 \\
\hline 48 & 958 & ALNTLVKQLSS & 968 \\
\hline 49 & 972 & AISSVLNDILSRLDKVEAEVQIDR & 995 \\
\hline 50 & 997 & ITGRLQSLQTYVTQQLIRA & 1015 \\
\hline 51 & 1028 & KMSECVLGQ & 1036 \\
\hline 52 & 1038 & KRVDFCGKGYHLMSFPQSAPHGVVFLHVTYVPA & 1070 \\
\hline 53 & 1077 & TAPAICHDG & 1085 \\
\hline 54 & 1090 & PREGVFVS & 1097 \\
\hline 55 & 1122 & VSGNCDVVIGIVNN & 1135 \\
\hline 56 & 1137 & VYDPLQPEL & 1145 \\
\hline 57 & 1160 & TSPDVDL & 1166 \\
\hline 58 & 1171 & GINASVVNI & 1179 \\
\hline 59 & 1185 & RLNEVAK & 1191 \\
\hline 60 & 1194 & NESLIDLQE & 1202 \\
\hline 61 & 1205 & KYEQYIKW & 1212 \\
\hline 62 & 1214 & WYIWLGFIAGLIAIVMVTIMLCCMTSCCSCLKGCCSCGSCCK & 1255 \\
\hline 63 & 1261 & SEPVLKGVK & 1269 \\
\hline
\end{tabular}


Other files

Suppl_File_3_Mutation_S_analysis.csv (92.69 KiB)

view on ChemRxiv • download file 